\title{
STRUCTURE OF GENTRAL AND EAST-CENTRAL VERMONT
}

WALTER S. WHITE AND RICHARD H. JAHNS

Division of the Geological Sciences

California Institute of Technology Contribution 423

Reprinted for private circulation from THE JOURNAL OF GEOLOGY

Vol. 58, No. 3, May 1950

PRINTED IN U.S.A. 


\title{
THE JOURNAL OF GEOLOGY
}

\section{May 1950}

\section{STRUCTURE OF CENTRAL AND EAST-CENTRAL VERMONT ${ }^{x}$}

\author{
WALTER S. WHITE ${ }^{2}$ AND RICHARD H. JAHNS ${ }^{3}$ \\ United States Geological Survey
}

The formations of central and east-central Vermont are exposed as a series of parallel belts that strike nearly north. Most of the rocks dip steeply, and many are overturned. With one possible exception, there seem to be no major repetitions within the sequence, and the order of formations from west to east appears to be the same as the order of their deposition. The formations are dominantly schist or phyllite, with varying proportions of arenaceous material. One thin formation, the Shaw Mountain, contains quartz conglomerate, calcareous tuff, and crinoidal limestone. The third-from-highest formation, the Waits River, is very thick and contains a large proportion of calcareous beds. The distance from the base of the lowest formation to the top of the highest, measured normal to bedding, is more than I00,000 feet; this large apparent thickness is believed to be not very much greater than the original thickness.

The metasediments have been intruded by granitic dikes and plutons, mafic dikes, and small ultramafic plutons.

Two principal stages of deformation are distinguished. During the earlier stage the rocks were folded, and a schistosity was developed nearly parallel to bedding. Throughout the area the minor folds of this stage indicate a consistent upward movement of rocks on the east with respect to those on the west. The folds plunge at low to moderately steep angles, typically northward.

Phenomena associated with the later stage of deformation decrease in intensity both eastward and westward from the belt underlain by the calcareous Waits River formation. At a distance from this formation, the rocks have prominent slip cleavage, and the earlier schistosity is folded. The minor folds plunge moderately to steeply northward on the western side of the area and more gently northward on the eastern. As the Waits River formation is approached, slip cleavage passes gradually into a schistosity that obliterates the earlier schistosity, and the intensity of later folding increases. In both the eastern and the western parts of the area the later minor folds indicate that the rocks of the Waits River formation have moved upward with respect to the formations on either side.

The central part of the belt underlain by the Waits River formation is marked by a huge arch, 10-20 miles across, whose axis is more or less parallel to the belt and plunges gently northward. This is shown to be an arch, not in bedding, but in the later schistosity and in the axial planes of large isoclinal folds that were formed during the later stage of deformation. The axial planes of three of these large isoclinal folds can be correlated across the crest of the cleavage arch at Strafford Village.

\section{INTRODUCTION}

The part of Vermont that lies east of the Green Mountains is underlain by a great thickness of Paleozoic metasedimentary and metavolcanic rocks. Most

${ }^{2}$ Published by permission of the Director, U.S. Geological Survey. Manuscript received December I9, 1949.

2 I033 Mine Street, Calumet, Michigan.

${ }^{3}$ California Institute of Technology, Pasadena, California. of the beds trend north, parallel to the mountains farther west, and have steep to vertical dips. Despite profound deformation, the upturned edges of the stratigraphic units crop out as a monotonously parallel series of bands throughout most of the region and suggest a relatively unbroken sequence of formations flanking the core of the Green Mountains proper. The rocks of the region are dominantly 
arenaceous and argillaceous, but one formation is distinguished by an abundance of calcareous beds. This was originally mapped as the "calciferous mica schist" by E. Hitchcock (I86I, pp. 475-488, pl. I), who traced it as a continuous belt, 2-25 miles wide, from the Canadian border to the southern boundary of Vermont. In central Vermont this calcareous formation lies within a few miles of the eastern boundary of the state, and in this latitude it is coextensive with a large area of complex structure that stands in sharp contrast to the simple structure of the arenaceous and argillaceous rocks in areas farther east and farther west. A preliminary description and a map of these areas are presented in this paper.

Figure I shows the location and extent of the area described here. The areas studied by the individual authors, as well as the source of information on other areas, is indicated in figure 2. Most of the work was done in connection with mapping programs of the U.S. Geological Survey during the period I937-I946. White mapped the Woodsville area in connection with his graduate studies at Harvard University.

During the course of the field investigations the writers planned to complete a study of the entire area before publishing their findings, but subsequently they were forced to postpone completion of this program by other, more pressing duties and commitments. Additional field work, lasting for several seasons, will be required before a full report on the structure and stratigraphy of the region can be attempted. Many important problems remain to be solved, in part because large areas in the East Barre and Randolph quadrangles, embracing critical structural and stratigraphic features, are yet unstudied. For this reason the writers here present a description of the area with more emphasis on the geometrical relationships than upon the mechanisms by which the various structural features were developed. Some reference to processes is inevitable, but such reference may be considered incidental to the primary purpose of this paper: to offer a preliminary geologic map and description of the area as a whole in the hope that, despite the gaps, these data will be of value to other workers in nearby areas and to all students of Appalachian geology.

None of the quadrangles mentioned above makes a satisfactory stratigraphic or tectonic unit in itself, and a knowledge of the geology in each is essential to an understanding of that in the others. For this reason the writers have conferred frequently during all stages of the work, and many of their ideas have been developed co-operatively from independent beginnings. This paper is intended as a summary of more detailed discussions that the writers expect to publish individually, and parts of it are necessarily mere abstracts of these more detailed descriptions. More than half the geologic map presented herein (fig. 2) was the product of the writers' own field work, but many gaps have been filled in from the other sources indicated. The preparation of the text was shared equally by both authors.

The region has been described, as a whole or in substantial part, by Edward Hitchcock (I86I), C. H. Hitchcock (1912), Richardson (1902, 1906, 1919a), and Doll (1945). The earlier studies were carried out by rough reconnaissance methods at times when few accurate base maps were available, and it is scarcely surprising that many geologic boundaries on the older maps are mislocated by a mile or more. In contrast, the recent report on the geology of the Strafford 


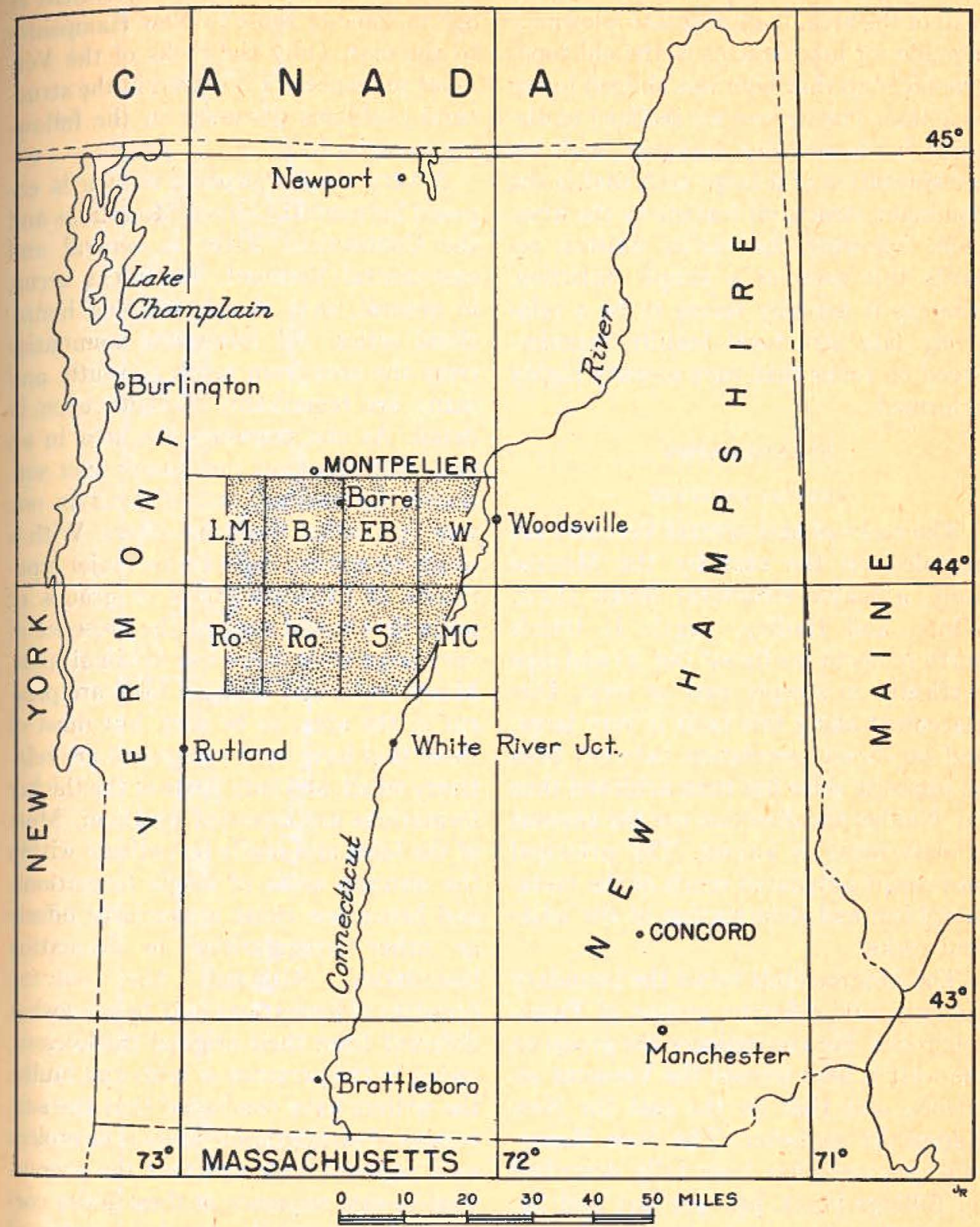

FIG. I.-Index map of Vermont and New Hampshire, showing locations of quadrangles discussed in text. $L M$, Lincoln Mountain; $B$, Barre; $E B$, East Barre; $W$, Woodsville; Ro, Rochester; $R a$, Randolph; $S$, Strafford; $M C$, Mount Cube. Stippled area is that shown in fig. 2. 
quadrangle is accompanied by a good map of the area, if appropriate allowance is made for inaccuracies in the old topographic map that Doll was obliged to use as a base. The writers are inclined to disagree fundamentally, however, with his interpretation of a large arch that is the dominant structural feature in the area. Doll, following the earlier writers, regards this arch as a simple anticline, whereas it actually seems to be a relatively late structural feature superimposed on rocks that were already highly deformed.

\section{STRATIGRAPHY}

GENERAL FEATURES

The rocks of east-central Vermont are bounded on the east by the Monroe fault, a major structural break (Eric, White, and Hadley, I94I). It trends north to north-northeast (fig. 2) and dips vertically to steeply east or west. Displacement along this fault is very large, and no direct correlation between beds on opposite sides has been achieved thus far. Neither the direction nor the amount of movement is known. The principal movement antedated much of the metamorphism and deformation of the adjacent rocks.

The Monroe fault forms the boundary between two different groups of Paleozoic rocks. For convenience the group on the west is here termed the Vermont sequence, and that on the east the New Hampshire sequence. The New Hampshire sequence has been fully described by Billings ( 1937 , pp. 472-495 and fig. 2), Hadley (I942, pp. II $7^{-I} 34$ ), and others and includes metamorphic rocks ranging in age from Ordovician to early Devonian. No rocks of the New Hampshire sequence lie west of the Monroe fault and within the area described in this paper, although some units in the
Vermont sequence may be equivalent in age to some of those in New Hampshire to the east. Only the rocks of the Vermont sequence are involved in the structural problems discussed in the following paragraphs.

A very thick Paleozoic section is exposed between the Green Mountains and the Connecticut River in central and east-central Vermont. The rocks occur, in general, as a steeply dipping homoclinal series. All formation boundaries cross the area from north to south, and many are remarkably straight, even in detail. As one traverses the area in an east-west direction, one passes over successive formations, each distinct in one way or another from the others. With a single exception, there are no major repetitions of lithologic units or groups of units that would suggest the presence of very large-scale thrusts or isoclinal folds. Many faults and isoclinal folds are present in the area, to be sure, but most of those that have been recognized are relatively small, and only parts of the thicker formations are repeated by them. Most of the folds and faults lie entirely within the outcrop areas of single formations, and hence few cause appreciable offsets or other irregularities in formation boundaries. Although the outcrop breadths of formations may be somewhat different from their original thicknesses, owing to the presence of folds and faults, the writers have concluded that the succession of stratigraphic units is unbroken on a regional scale and that the present west-to-east sequence of these units corresponds essentially to their order of deposition.

The dip of beds, because of prevailing steepness, cannot be reliably used to determine top and bottom of the section. Fortunately, however, there is other evidence for the relative ages of the rocks: 


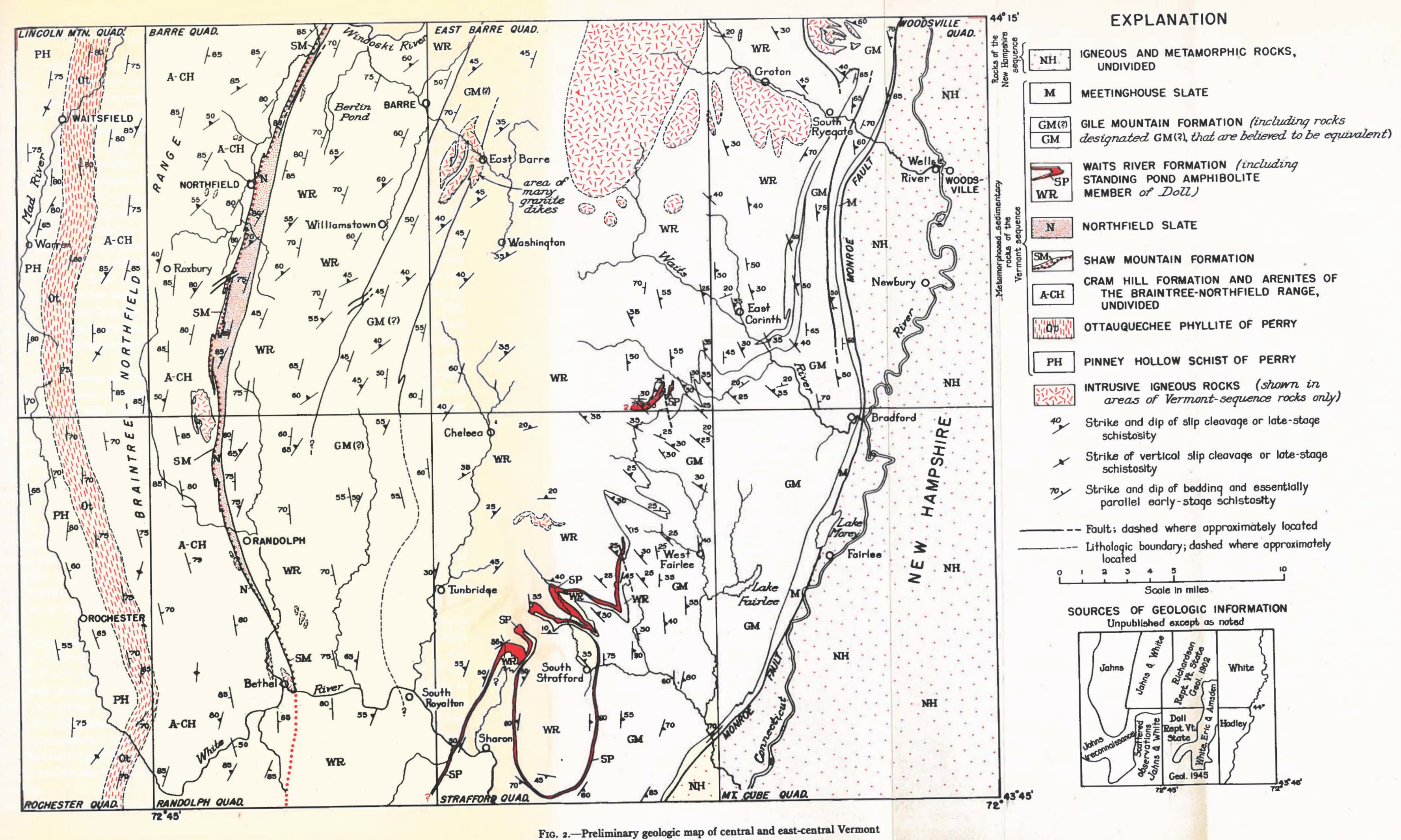


(I) A basal conglomerate of one formation, exposed in the Barre quadrangle, contains rock fragments derived from the next formation to the west (Currier and Jahns, 194I, p. 1502), which indicates a westward increase in the age of the section. (2) Entirely compatible with this are the orientations of ripple marks and cross-bedding in several quartzite beds farther down in the section. (3) Intrinsically less reliable as evidence of top and bottom are the prevailing pattern and attitude of minor folds and the relation of bedding to cleavage; these are described more fully in connection with the structure of the area. These small-scale structural features also indicate that the formations are progressively older from east to west.

All the stratified rocks and some of the igneous rocks have been metamorphosed. The metamorphism was both dynamic, as shown by widespread foliation with oriented micas, and thermal, as revealed by the porphyroblastic growth of hightemperature metamorphic minerals. In the region as a whole, the thermal peak of the metamorphism postdated most of the dynamic metamorphism. Numerous large porphyroblasts of chlorite, muscovite, biotite, garnet, and staurolite cut at random across cleavage planes and are typically unbroken and unrotated except in the areas of highest thermal metamorphism.

A tentative stratigraphic column of the rocks of the Vermont sequence, as exposed in the Barre quadrangle, is shown in figure 3 , and the individual formations are briefly described below. Fuller descriptions, including discussion of the regional metamorphism, are being prepared for detailed reports on individual quadrangles within the large area treated in this paper.

The thicknesses of the various strati- graphic units are discussed separately after the lithologic descriptions.

PINNEY HOLLOW SCHIST OF PERRY

The Pinney Hollow schist, at the base of the section considered in this paper, is underlain by a thick series of quartzose schists, quartzites, dolomites, and conglomerates that forms the core of the Green Mountains. It is the lowermost stratigraphic unit thus far traced for any considerable distance in central Vermont and is known to extend north for more than 70 miles from the type area in the township of Plymouth (Perry, I929, p. 24) to points north of Stowe. The breadth of outcrop of the Pinney Hollow rocks is more than 12,000 feet in the latitude of Rochester and is at least II,000 feet near Warren. In the Rochester and Lincoln Mountain quadrangles (fig. 2) the outcrop belt is traversed at very acute angles by the White River and the Mad River; it also includes some steeply sloping highland areas.

The dominant rock types in the Pinney Hollow schist are fine-grained, thinly laminated quartz-sericite-chlorite phyllite and schist, and coarser quartz-chlorite schist of characteristic bluish to bluish-green color. The latter may well be of volcanic origin. The two general rock types are intergradational, both along and across the strike. Thin beds of impure quartzites are locally conspicuous near the base of the formation, and thin beds of dark-gray to black schist and phyllite occur in the upper third of the formation. Very thin and platy beds of buff dolomite and limestone also are present near the top. Most of the chloritic schist and phyllite beds contain abundant metacrysts of sodic plagioclase, especially in that part of the belt north of Rochester. This albitization clearly postdates all folding, as well as 
the dynamic metamorphism of the rocks. It bears no direct genetic relation to stratigraphy, although the abundance of the feldspar varies greatly with lithologic variations in the host rock. Such albitization has strongly affected most of the schists and gneisses in the Green Mountain region of central and northern Vermont.

\section{OTTAUQUECHEE PHYLLITE OF PERRY}

The Ottauquechee phyllite, named by Perry ( 1929, p. 27) from excellent exposures on the Ottauquechee River in the township of Bridgewater, consists of such distinctive rock types that it constitutes a valuable marker unit in a very thick and otherwise monotonous noncalcareous section. Dark-gray quartzose phyllite, thick-bedded, green to dark-gray vitreous quartzite, and pale to bluishgreen quartz-chlorite-sericite schist and impure quartzite are intimately interbedded. They grade into one another along the strike in such an irregular manner that the formation is not readily divisible into separate members.

Several hundred feet of quartzite and interbedded schist and phyllite lie near the middle of the Ottauquechee section for a strike distance of about 18 miles north from Rochester. For a somewhat shorter distance the base of the formation is marked by a second quartzite-rich zone at least 300 feet thick. Elsewhere the transition between the Ottauquechee phyllite and the underlying Pinney Hollow schist is marked by a downward gradation from interlayered green schist, gray phyllite, and platy greenish quartzite to green schist with very minor quartzite. In many places this transition zone is broad and poorly defined; where relations are further complicated by minor folding and shearing, the boundary between the two formations cannot be precisely assigned.

The Ottauquechee phyllite underlies areas of low to moderate relief. It is $6,000-8,500$ feet wide and, for much of its length, is flanked by the BraintreeNorthfield Range on the east and by a narrow ridge of schist and phyllite of the Pinney Hollow on the west. The area underlain by the Ottauquechee is perched 600-700 feet above the valleys of the White River and Mad River, which are little more than a mile to the west.

\section{ARENITES OF THE BRAINTREE-NORTH- FIELD RANGE}

Above the Ottauquechee phyllite is a very thick sequence of arenaceous rocks that is not readily divisible into stratigraphic units of great continuity. These rocks include the "Bethel schist," "chlorite schist," "hydromica schist," "lower Cambrian rocks," most of the "Missisquoi group," and some of the "Algonkian rocks" of Richardson (Richardson, IgI6, rgrgb, 1924, I927; Richardson and Camp, I9I9; Richardson and Cabeen, I92I, I923) and are here termed "arenites of the Braintree-Northfield Range," pending a more detailed description and stratigraphic analysis. They underlie Braintree Mountain and the Northfield Mountains and extend east and west to the valleys that flank this range. The outcrop belt is 42,000 feet wide immediately north of the Barre and Lincoln Mountain quadrangles but tapers somewhat to the south. In general, the country underlain by these rocks is rugged, with narrow valleys and steep, locally irregular slopes.

The characteristic dark-colored phyllite and quartzite beds of the Ottauquechee phyllite are overlain conformably by greenish quartz-chlorite-sericite schist that in many respects is like much of the 


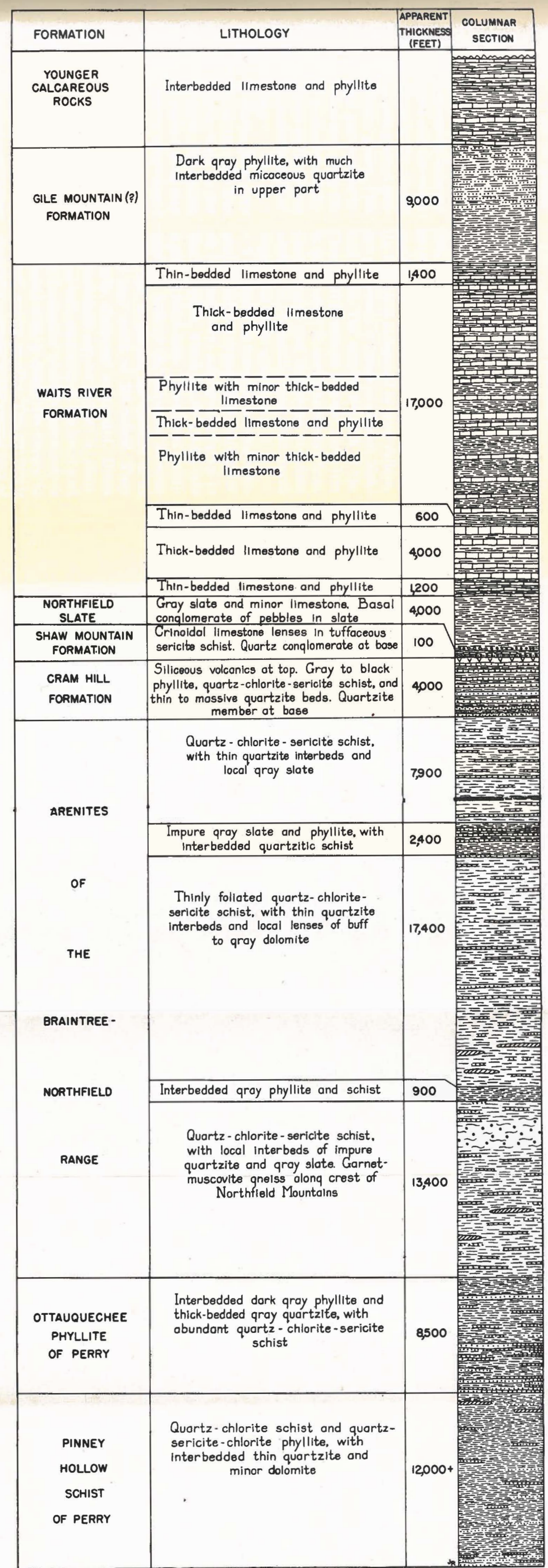

Fig. 3.-Generalized columnar section of the stratified rocks of central Vermont. Younger calcareous rocks are shown above the Gile Mountain (?) formation on the basis of two assumptions, both discussed in rocks are shown above the Gile Mountain (?) formation on the (asis of two assumptions, both discussed in Mountain formation farther east, and (2) a fault that repeats this formation lies east of the eastern border of the GM (?) unit. No beds that can be correlated with the Meetinghouse slate of east-central Vermont have been recognized in the Barre quadrangle. 
Pinney Hollow schist. It contains local interbeds of impure quartzite, gray slate, dark-gray phyllite, and sericite-rich schist; where its lower parts are more gray than green, it is not easily distinguished from the phyllitic upper parts of the Ottauquechee. Green schist of probable volcanic origin occurs in several parts of the section. Some lenses of homogeneous, buff-colored dolomite are exposed on the steep western slopes of the Northfield Mountains, but none appears to be satisfactory as a marker unit. The highest parts of the mountains, between the latitude of Northfield and the north edge of the Barre quadrangle (fig. 2), are underlain by a very coarse-grained garnetiferous quartz-muscovite gneiss. This rock grades into typical quartz-chloritesericite schist, both across and along the strike, and evidently owes its present distinctive lithology more to a higher degree of metamorphism than to distinct differences in original lithology.

A narrow belt of interbedded gray phyllite and schist can be traced across some very rugged country high on the east side of the Northfield Mountains, but probably does not make a good map unit for a strike distance of more than 7 miles. It is bounded on the east by thinly foliated, green quartz-chlorite-sericite schist similar to that on the west. This schist also contains lenses of buff to gray arenaceous dolomite. Higher in the section the schist is distinctly more quartzose and platy and has closely spaced chloriterich partings. Dark-gray to greenish-gray quartzite and splintery dark-gray schist appear locally.

These predominantly green arenaceous rocks are overlain by a well-defined unit of impure slate and phyllite, with interbedded quartzite and quartzose schist. Most of the quartz-rich beds occupy a central or near-central position in this unit, the total outcrop breadth of which is about 2,400 feet. The upper part of the arenite sequence, above the slate-phyllite marker unit, consists of additional green quartz-chlorite-sericite schist, with thin quartzite interbeds and local gray slate.

CRAM HILL FORMATION

The Cram Hill formation is known to extend from Randolph to points north of the Barre quadrangle, or for a total distance of about 27 miles. It is named for an area of excellent exposures on Cram Hill, $3 \frac{1}{2}$ miles south-southeast of Roxbury (Currier and Jahns, I94I, pp. I495I 496 ). Northward from the type locality the formation is exposed in river valleys, but southward it forms prominent highland areas. The outcrop breadth of the Cram Hill formation is about 4,000 feet in most areas. It varies somewhat from place to place but, in general, broadens northward, especially near the north edge of the Barre quadrangle.

The formation comprises several intergradational rock types. Most characteristic is a splintery, pale greenish-gray to black phyllite, which locally grades into a gray to black slate. These rocks constitute the bulk of the sequence in some areas but, in general, are confined to its upper part north of Northfield. They gradually disappear northward. Green quartz-chlorite-sericite schist is abundant as well, especially in the lower part of the formation, where it commonly is associated with a distinctive silvery to greenish sericite phyllite. This phyllite is especially common in the central part of the Barre quadrangle. Flows and clastic volcanic rocks of silicic composition mark the top of the formation at several places north of the type locality but do not appear to be very continuous. Sills and dikes of greenstone are very abundant in many parts of the formation. 
Thin, platy beds of quartzite are common in many parts of the Cram Hill formation, and somewhat thicker beds occur near its base. A distinctive unit, named the Harlow Bridge quartzite member (Currier and Jahns, I94I, p. I493), marks the base of the formation and in many places is the sole means of distinction between it and the arenaceous green schists of the Braintree-Northfield sequence. This member is composed of massive to thin-bedded quartzite with abundant intercalated chlorite-rich schist. It thickens from north to south but contains progressively less quartzite in the same direction.

\section{SHAW MOUNTAIN FORMATION}

The Shaw Mountain formation, a thin unit of considerable stratigraphic significance, occurs at the horizon of Richardson's "Cambrian-Ordovician" boundary in central Vermont. This boundary, which separates noncalcareous rocks on the west from calcareous strata on the east, has been traced by earlier geologists from the north boundary of Vermont to the Vermont-Massachusetts state line. Owing in part to its thinness, the Shaw Mountain formation is not exposed continuously, but in most places it is easy to define its location within rather narrow limits. This unit has been mapped from Bethel north to points in the Montpelier quadrangle, 42 miles away, and has been traced in reconnaissance by Currier and Jahns to the Canadian boundary.

The Shaw Mountain formation consists of three lithologic types (Currier and Jahns, I94I, pp. I496-I499). At the base is a massively bedded quartz conglomerate that ordinarily forms high, bold outcrops. It is lithologically unique in central Vermont and in several respects resembles the Clough formation of New Hampshire (Billings, I937, pp.
$48 \mathrm{I}-483$ ). The pebbles and rare cobbles, chiefly vein quartz, generally have been much elongated by tectonic action. The matrix consists mainly of quartz with subordinate mica.

The conglomerate grades upward into sericite schist that is distinctly calcareous and tuffaceous in many places. It is white to pale greenish-white where fresh, but weathers to a light brown or tan. White to slightly bluish crinoidal limestone occurs as thin beds and lenses near the top of the formation. It is characteristically interlayered with the tuffaceous beds, and at many places occurs as distinct lenses a foot or less in thickness. This fossiliferous limestone has been found throughout the length of the Barre quadrangle and as far south as Randolph (Currier and Jahns, I94I, p. I499).

The thickness of the Shaw Mountain formation is extremely variable. In many places it is absent entirely, and in others it has an outcrop breadth of 2,000 feet or more. The quartz conglomerate occurs typically as large, podlike masses separated along the strike. Most of the abrupt changes in thickness seem readily ascribable to tectonic forces rather than to variations in original sediments, and probably represent large-scale boudinage. Some of the variations in thickness of the tuffaceous rocks, however, may be due in large part to original deposition. In general, the conglomerate thickens southward to a probable maximum of 250 feet in the southern part of the Barre quadrangle. North of this area the volcanic parts of the formation reach their maximum thickness of 700 feet or more. In most places, however, the entire formation is less than 50 feet thick.

NORTHFIELD SLATE

The term Northfield slate, as redefined by Currier and Jahns (I94I, p. I5OI), applies to a sequence of gray slates that 
lie unconformably above the Shaw Mountain formation and conformably beneath the calcareous and argillaceous rocks of the thick Waits River formation. In general, this unit corresponds to beds mapped in central Vermont as "Memphremagog slates" by Richardson (I906). The belt of slate, about 4,000 feet wide in much of the Barre quadrangle, extends for a known strike distance of 32 miles. North of Montpelier it is very thin, and it tapers out entirely south of Randolph (fig. 2). It is a resistant unit and characteristically forms prominent ridges wherever it is thick enough to control the topography.

Most of the Northfield slate is light- to dark-gray slate with very minor interbeds of dense, bluish-gray limestone. Zones of small siliceous nodules and I- to 30 -inch layers of conglomerate are present in the lower third of the unit. The base of the formation also is marked by very thin beds and lenses of conglomerate, and in places a poorly exposed basal conglomerate lies upon rocks of the Shaw Mountain and Cram Hill formations with what appears to be a slight erosional unconformity. This unit contains abundant fragments of rock types characteristic of the Shaw Mountain and Cram Hill formations. Most diagnostic among these are scattered pebbles of crystalline limestone and quartz conglomerate. One limestone pebble containing a crinoid fragment was found in the north part of the Randolph quadrangle (Currier and Jahns, I94I, p. I 502). Thin, platy limestone beds occur above the conglomerate at several localities, but their stratigraphic position does not appear to be consistent over considerable distances along the strike. Additional thin limestone beds are present at the top of the formation and mark an upward gradation into the calcareous Waits River formation.
WAITS RIVER FORMATION

General statement.-The rocks above or east of the Northfield slate include both calcareous and noncalcareous beds, chiefly phyllites and schists. In any traverse eastward from the border of the Northfield slate in the Barre quadrangle, one crosses in succession (I) $4^{-6}$ miles of predominantly calcareous rock, (2) 2-4 miles of mica schist, phyllite, and quartzmica schist, (3) I 2-I 5 miles of calcareous rock, and (4) 2-8 miles of mica schist and quartz-mica schist. The last unit is bounded on the east by the Monroe fault. The first and third belts are lithologically almost identical, as are the second and fourth. For the purpose of the following lithologic descriptions, it is assumed that there is only one calcareous unit and only one noncalcareous unit and that these two units have been structurally repeated. The basis for this assumption is discussed later. The calcareous unit is termed the Waits River formation (Currier and Jahns, I94I, p. I49I), and most of the noncalcareous unit is called the Gile Mountain formation (Doll, I945, pp. 18-19). The easternmost portion of the eastern noncalcareous unit is lithologically distinct and has been called the Meetinghouse slate (Doll, I945).

Lithologic features. - The Waits River formation is a thick series of interbedded impure limestones, calcareous mica schists, phyllites, quartz-mica schists, and platy impure quartzites. The rocks are less metamorphosed in the Barre and Randolph quadrangles than in areas to the east, and most of the argillaceous types are there properly termed "phyllites." All the calcareous rocks have been recrystallized and hence are most accurately termed "marble." In accord with long-established local usage, however, the authors refer to them as "limestones" in this paper.

Calcareous and noncalcareous rocks 
are interbedded on large and small scales; beds and groups of beds range in thickness from a fraction of an inch to many tens of feet. Some sections several hundred feet in apparent thickness are dominantly calcareous, whereas others contain little or no carbonate minerals. Further, there is a complete gradation in lithologic character from quartzose marble, that contains very little mica, to schist or phyllite, that contains only traces of carbonate material. All intermediate types are known. Calcareous beds constitute nearly half the Waits River formation, and its total carbonate mineral content probably amounts to about I 5 per cent.

The most distinctive rock type is quartzose limestone with subordinate mica, which forms massive beds I inch to 40 feet thick. These rocks are white to bluish-gray where fresh, but at the surface they are weathered to a characteristic dark-brown color and a spongy, cellular crust. Calcareous mica schist occurs in most outcrops that contain quartzose limestone. It is generally coarsely crystalline and contains abundant biotite, and its carbonate content is clearly indicated by its typically dark-brown, friable weathered surfaces.

The bulk of the noncalcareous part of the formation consists mainly of darkgray to black mica schist and quartzose mica schist. Micaceous quartzite is subordinate but locally is well developed in the southern part of the Barre quadrangle and adjacent parts of the Randolph and East Barre quadrangles. Many outcrops show alternations between schistose impure quartzite and quartzose schist, with individual units ranging in thickness from a fraction of an inch to about 6 inches.

The relative straightness of geologic boundaries within the Waits River for- mation of the Barre quadrangle makes it possible to define several members, each characterized by a distinctive ratio of calcareous to noncalcareous beds, by a distinctive average thickness of its calcareous beds, or by a combination of these features. Such subdivisions are indicated graphically in figure 3. Most of the units persist for the entire length of the Barre quadrangle and can be recognized with little difficulty in the field. Farther east, where deformation has been more complex, attempts at subdivision have met with little success, except very locally and where accompanied by extremely detailed mapping.

Standing Pond amphibolite member of Doll.-The name Standing Pond was applied by Doll (I945, p. I7) to a thick layer of amphibolite in the uppermost part of the Waits River formation (Memphremagog formation in Doll's report) as exposed in the Strafford and southeastern East Barre quadrangles. This unit forms the boundary between the calcareous schists of the Waits River formation and the noncalcareous rocks of the overlying Gile Mountain formation in the southern third of the Strafford quadrangle. Farther north, however, calcareous rocks stratigraphically overlie the amphibolite, and this overlying calcareous unit appears to increase in thickness northward and westward.

The rocks of Doll's Standing Pond amphibolite member range from finegrained needle amphibolite to coarse hornblende schist. All varieties are distinctly layered and schistose, with the schistosity parallel to the layering in most places. Coarse garnet schist is common along the borders of the amphibolite. Despite intensive search, nothing resembling an amygdaloidal flow-top or pillow-lava has been found in these rocks. On the other hand; there is an equal lack 
of broad or detailed evidence that the rock is intrusive. The amphibolite, as mapped, gradually transgresses bedding if one considers that the boundary of calcareous and noncalcareous rocks is parallel to bedding. One might assume, however, that this boundary, rather than the amphibolite, is transgressive. Because of its great value as a marker horizon, the Standing Pond is tentatively treated as a volcanic unit in the Waits River formation.

\section{GILE MOUNTAIN FORMATION}

General statement.-The typical rocks of the Gile Mountain formation (Doll, 1945) may be defined as including those that lie between the Meetinghouse slate on the east and the dominantly calcareous rocks of the Waits River formation on the west (fig. 2). A broad belt of noncalcareous phyllites, schists, and impure quartzites in the southeastern part of the Barre quadrangle and adjacent parts of the Randolph and East Barre quadrangles $[G M$ (?) in fig. 2] is here tentatively correlated with the Gile Mountain formation of the Strafford quadrangle.

As the term is used herein, the Gile Mountain formation includes the rocks at the type locality, Gile Mountain in the Strafford quadrangle, and most of those rocks mapped by Doll (1945) as Gile Mountain formation elsewhere in the Strafford quadrangle. It does not include, however, any of the rocks exposed east of the Monroe fault in the southeastern corner of this quadrangle. Many of these rocks are lithologically similar to those of the Gile Mountain formation, but they are areally continuous with the Ordovician (?) Orfordville formation of the Mount Cube quadrangle (Hadley, 1942, and unpublished map of the Vermont part of Mount Cube quadrangle), into which they can be traced along the strike. The stratigraphic equivalence of the Orfordville and Gile Mountain formations has not been demonstrated.

The boundary between the Waits River and Gile Mountain formations is transitional in most places and probably does not represent a time line. In areas of good exposure the transition zone between distinctly calcareous and distinctly noncalcareous rocks rarely exceeds 200 feet in width. The calcareous rocks, on the other hand, are less likely to crop out than the noncalcareous rocks, and the contact in some areas may be mislocated by as much as a quarter of a mile, particularly where exposures are poor and deformation has been intense. Errors of this order of magnitude may exist in the northern third of the Strafford quadrangle, the southeastern ninth of the East Barre quadrangle, and the southwestern ninth of the Woodsville quadrangle (fig. 2). At such places, noncalcareous rocks of the Waits River formation may well have been mapped locally as the Gile Mountain.

Lithologic features.- The rocks of the Gile Mountain formation include darkgray to black phyllite and mica schist, gray quartzose phyllite and quartz-mica schist, and light-gray micaceous quartzite. The argillaceous rocks of the Barre quadrangle and of the eastern border of the formation in the Woodsville quadrangle are phyllitic, whereas those of the East Barre and Strafford quadrangles are schistose. This difference appears to be due entirely to differences in degree of metamorphism, and all gradations between schist and phyllite are present.

In their most typical facies, the Gile Mountain rocks include almost equal quantities of light-gray arenaceous schist and dark-gray micaceous schist or phyllite. The two types commonly alternate in layers that range from microscopic 
thickness to as much as 6 inches. Micaceous quartzite, containing as much as 80 per cent quartz, occurs locally throughout the formations, and at some places constitutes more than half the exposed rock. Pure quartzite is extremely rare. Where micaceous quartzite is present in minor quantities, individual beds rarely exceed a foot in thickness, but where it is abundant the beds are as much as 30 feet thick. The amount or proportion of micaceous quartzite increases from north to south in both belts shown as Gile Mountain formation in figure 2.

Though typically noncalcareous, the Gile Mountain formation does contain a few scattered beds and thicker units of calcareous rock. These are lithologically indistinguishable from typical Waits River rocks and are more abundant near the boundary of that formation than elsewhere. The presence of such material in the Gile Mountain formation and the presence of rocks with typical noncalcareous Gile Mountain lithology in many parts of the Waits River formation suggest that these formations are merely different sedimentary facies of a single depositional unit of very great size. As previously noted, the boundary between them probably is not a time line.

\section{MEETINGHOUSE SLATE}

The rocks between the Monroe fault and the Gile Mountain formation in the Woodsville and Mount Cube quadrangles contain very little micaceous quartzite or quartz-mica schist. This belt of slaty and phyllitic rocks is designated the Meetinghouse slate (Doll, I945, p. I9). It is about 2,500 feet wide in the north-central part of the Mount Cube quadrangle. The western boundary is transitional.

The Meetinghouse slate has not been identified as such in the western belt of the Gile Mountain (?) formation in the Barre quadrangle, but a large part of the noncalcareous belt in the Barre quadrangle contains a higher-than-average proportion of phyllite.

ROCKS ABOVE THE GILE MOUNTAIN FORMATION AND MEETINGHOUSE SLATE

Any rocks that may once have overlain the Gile Mountain formation and Meetinghouse slate in the Woodsville, Mount Cube, and Strafford quadrangles have been cut out along the Monroe fault. The existence of some younger calcareous rocks, as shown in figure 3 , is suggested by one possible explanation for the occurrence of the Gile Mountain (?) formation in the southeastern part of the Barre quadrangle. This interpretation is discussed farther on (pp. 206-7), in connection with the structure of the western tectonic belt.

\section{THICKNESS}

The original thicknesses of formations in central and east-central Vermont cannot be readily or accurately determined. The apparent thicknesses ${ }^{4}$ correspond closely to the widths of outcrop belts in the steeply dipping parts of the section west of the Waits River formation but are distinctly less than the widths of units within the Waits River formation itself, where dips are less steep. The apparent thickness of any of these units may be greater than the original thickness because of repetition of beds by minor folds and reverse faults, both common in the region. A thickening factor of more than 2, attributable to such repetition, has been calculated for parts of the Cram Hill and overlying formations,

${ }^{4}$ Apparent thickness, as used here, may be defined as the average distance between the upper and lower boundaries of a stratigraphic unit measured perpendicular to a plane that most nearly represents the attitude of the unit as a whole. 
which contain numerous beds of contrasting competence. Even greater thickening has taken place in the Waits River and Gile Mountain formations of the Mount Cube and Strafford quadrangles (fig. 2).

On the other hand, thickening by structural repetition is accompanied by divergence between the trend of formation boundaries and the strike of bedding as measured in outcrops, and over much of the area such divergence is either inconspicuous or absent. Indeed, the apparent thickness of some units may be appreciably less than the original thickness, owing to rock flowage, where the cleavage makes a low angle with bedding and formation boundaries (Cloos, I947, pp. 9ro-grI), as it does in most of the western part of the area. The net result of these two opposing factors makes it probable that the average apparent thicknesses, given in table I, are somewhat less than twice the respective original thicknesses.

\section{AGE}

The rocks of the Vermont sequence are so sparsely fossiliferous that age determinations are very difficult to make. Most age assignments necessarily have been based upon stratigraphic correlations over great distances or upon other indirect evidence and have ranged from Cambrian to Devonian. Conclusions reached by different investigators have varied considerably, as to both position and range of certain rock units in the time scale. The most recent discussions on the subject are in publications by Richardson (I9I9a), Currier and Jahns (I94I), and Doll (1945). Although detailed analysis of the problem is beyond the scope of this paper, a brief summary of existing evidence may well be in order.

The Cram Hill formation, immediate- ly beneath the "Cambrian-Ordovician boundary" of Richardson, is probably of Trenton, or Middle Ordovician age (Currier and Jahns, I94I, pp. 1496, I508I 509), on the basis of a correlation along the strike with graptolitic slates at Castle Brook, Magog, Quebec (Clark, I934; Ambrose, I942). These slates are overlain nonconformably by fossiliferous strata of Silurian and Devonian age (Clark, 1934, I936; Ambrose, 1942). The position of the actual Cambrian and Ordovician boundary in central Vermont is not

\section{TABLE 1}

\section{Formation Thicknesses}

Meetinghouse slate

Gile Mountain formation

Waits River formation

Northfield slate

Shaw Mountain formation

Cram Hill formation

Arenites of the Braintree-Northfield Range

Ottauqueche phyllite $\cdot{ }^{-} 42,000$

Ottauquechee phyllite of Perry . $-8,500$

Pinney Hollow schist of Perry . - I2,000

Total .

$-100,600 \dagger$

* Original thickness ranges from 0 to about gos $\mathrm{ft}$. fOr about 19 miles.

known, but the base of the Ordovician must lie west of the Cram Hill strata. It might not be represented by a distinct structural or stratigraphic break and hence might well be within the sedimentary section dealt with in this paper.

The Shaw Mountain formation is not older than Middle Ordovician, lying as it does upon the Cram Hill formation. Moreover, it contains crinoid remains of Middle Ordovician or younger age (Currier and Jahns, I94I, pp. I500-I501). The overlying Northfield slate has not yet yielded undoubted fossil material that can be used directly as a criterion of age. "Graptolites" of Beekmantown age have been reported from some beds of slate, phyllite, and limestone, but these 
forms appear to be inorganic in origin (Foyles, I93I; Currier and Jahns, I94I, pp. I 505-1 506). Moreover, a Beekmantown age is not compatible with the known relation between the Northfield and underlying formations.

The Waits River and Gile Mountain formations, according to Doll (1943a,b), contain fossil remains of probable Silurian and Lower Devonian ages, respectively. The organic origin of these forms has been doubted by some geologists, despite the arguments put forward by Doll and others, and for this reason the consequent age assignments should be viewed as tentative, pending the discovery of better-preserved material. Moreover, at least the lower part of the Waits River formation appears to be Ordovician in age, on the basis of fossil evidence recently discovered near East Montpelier Center by W. M. Cady (oral communication). Crinoidal limestone was earlier reported (Richardson, I902) from within the Waits River formation at Derby, Vermont, and a possible crustacean was noted from the Ordovician terranes of Northfield (Richardson, I929b, p. 245). Forms of possible Trenton age also were reported from other strata in Northfield (Richardson and Maynard, I939, pp. 9596). None of these forms was considered diagnostic, and specific localities were stated for very few of them.

Most students of Vermont geology agree that the Waits River formation is equivalent to at least a part of the Tomifobia formation of southern Quebec (Clark, 1934). The geologic continuity and marked lithologic similarity of these stratigraphic units cannot be denied. Those who have worked in the Quebec area during the last sixty years have concluded that the Tomifobia is Ordovician (Ells, I887; Kerr, I923; Clark, I934; Ambrose, I943). Ambrose (1942) states that no diagnostic fossils have been found in this formation, but Clark (personal communication, I94I) reports that a fauna of undoubted Ordovician age occurs in at least its lower part.

None of the rocks of the Vermont sequence is younger than the principal orogeny that is recorded in the region. As pointed out by Billings (1937, p. $5^{18}$ ), this orogeny in western New Hampshire was later than early Devonian and earlier than Triassic and antedated the intrusion of igneous rocks that probably are Mississippian (Williams and Billings, 1938, p. 1025). The Northfield slate, Waits River formation, Gile Mountain formation, and Meetinghouse slate of the Vermont sequence, therefore, are known to be no older than Middle Ordovician, and, as they were affected by the principal orogeny, none of them is younger than late Devonian.

\section{IGNEOUS ROCKS}

BARRE GRANITE

The dominant igneous rocks of the region are intrusive quartz diorite, granodiorite, quartz monzonite, and granite, here grouped under the single designation, Barre granite. They occur principally in the northern part of the area and probably represent a single magmatic epoch and province. The granites near Barre, typical of the group, have been described by Finlay (I902), Balk (I927), and others, and all the commercial granites have been described by Dale ( 1923 , pp. I04-IO8, II3-II8, I 2I-I43).

The intrusive masses in the BarreEast Barre area (fig. 2) are elongate, with boundaries generally parallel or subparallel to the bedding or schistosity of the adjacent stratified rocks. Few of them exceed 5 miles in length. Small subconcordant plutons of the same type of rock have been mapped in the northern part 
of the Woodsville area. A much larger area in the northeastern part of the East Barre quadrangle is underlain by granitic rocks (Richardson, I902) similar to the Barre granite. In this area exposures are poor, and the boundaries of the igneous masses never have been mapped in detail, so neither the nature nor the size of individual intrusives is known. Relations elsewhere suggest that the large body of granitic rock shown in the northeastern part of the East Barre quadrangle (fig. 2) may actually comprise numerous smaller bodies with intervening septa of stratified rocks.

The Barre granite includes rocks that have a wide range in composition. Most contain ro-30 per cent quart $z$, and $35^{-65}$ per cent plagioclase. The potash feldspar is microcline, the plagioclase is oligoclase to andesine. Biotite is the only dark mineral, and muscovite, though generally present, constitutes less than 5 per cent of most rock types. Pegmatites are not common.

The granitic rocks are believed to have been forcefully injected into the schists that now enclose them. All contacts are sharp. Highly feldspathized schist or other hybrid contact rocks are rare and are distinctly localized in all areas studied in detail. The composition of the rocks intruded into calcareous schists does not differ from that of rocks intruded into noncalcareous schists. There is abundant local evidence that, on a small scale, the intrusives made way for themselves by forcing apart the schist walls; in places the schists are bulged out on a larger scale around the areas of intrusion. Some of the plutons differ from those wholly emplaced by stoping (Billings, r 942 , p. 293) in their elongate form, in their concordant and subconcordant relations with the wall rock, and in the scarcity of inclusions with random orientation.

Though broadly concordant with the bedding or schistosity of the enclosing rocks, the plutons of Barre granite locally transect, at low or high angles, the structural features of the enclosing sediments. Dikes and stringers of granite or granodiorite cut across schistosity at many places, and locally cut sharply across the axial planes of folds in the schistosity. Inasmuch as these folds represent the last stage of major deformation in the region, the Barre granite is believed to have been emplaced during the closing stages of this deformation, or in part after the deformation had ceased. That they were not intruded long after the deformation is shown by their spatial relation to zones of metamorphism in the metasedimentary rocks.

Most of the granitic rocks lie within a broad area of highest thermal metamorphism in the region. Furthermore, lines of equal metamorphism (isograds), as traced across the area, bulge out around individual plutons, with the bulges convex toward rocks of lower metamorphic rank. These close spatial relationships suggest not only that intrusion and regional thermal metamorphism were associated but that they were not widely separated in time. Inasmuch as the thermal metamorphism overlapped the final stage of major deformation, as shown by the fact that porphyroblasts are locally, but not generally, deformed and rotated, it is probable that the intrusion of granitic rocks likewise took place near the close of this deformation.

\section{OTHER GRANITIC ROCKS}

A mass of medium-grained binary granite, distinctly coarser than the Barre granite, lies in arenaceous rocks beneath the Shaw Mountain formation north- 
northwest of Randolph (figs. 2 and 4). It is about 2 miles in exposed length and 4,000 feet in maximum width and hence is much more pluglike than the typical Barre plutons. Its sides are essentially parallel with the wall-rock structure, and at its ends it is complexly interfingered with the wall rock. The granite evidently was emplaced along the east side of a much narrower dioritic mass near the base of the Cram Hill formation. The thick Harlow Bridge quartzite member of the Cram Hill formation is almost completely cut out, and the rocks higher in the section are strongly bulged to the east (fig. 2). Parts of the Cram Hill section appear to have been thickened by close folding at the ends of the granite pluton, but a substantial part of the metamorphosed sedimentary rocks is clearly missing from the area of intrusion (fig. 4).

The granite contains few inclusions, although septa of country rock are abundant along its north and south margins. It is faintly foliated in places, almost structureless in others, and its composition is nearly uniform over large areas. There is little evidence for large-scale replacement of country rock, nor is there positive evidence for emplacement by stoping. The structural relations indicate mechanical injection of some sort, possibly involving an upward punching of country rock. A well-defined aureole of moderate-rank metamorphism surrounds this pluton and is broadest in the country rock that lies to the north.

Several small subconcordant plutons exposed in the area between Randolph and Bethel (fig. 2) consist of very lightcolored quartz monzonite. A sill-like or phacolithic mass of medium-grained binary granite was mapped by Doll (I945) in the north-central part of the Strafford quadrangle. Dikes, sills, and elongate plugs of medium-grained granite occur in the upper part of the arenite sequence near Northfield, particularly in the westcentral and northwestern parts of the Barre quadrangle. None of these granitic rocks has been definitely correlated with the Barre granite.

\section{BASIC ROCKS}

Numerous dikes and sills of greenstone and chlorite schist occur in the pre-Shaw Mountain section, particularly in parts of the Pinney Hollow and Cram Hill formations. They also are abundant in the upper part of the arenite sequence beneath the Cram Hill, where they locally constitute a substantial proportion of the section. No rocks of this type are known from the Waits River formation, although a few have been noted in the eastern belt of the Gile Mountain formation. They consist mainly of epidote, chlorite, ankerite, and other secondary minerals and closely resemble the dikes that occur in the Albee formation in New Hampshire (Billings, I937, pp. 5I2-5I5) and east of the Monroe fault in the Woodsville area of Vermont. In areas of moderate- or high-rank metamorphism, these rocks contain hornblende, and many are typical amphibolites.

Some of the greenstones are of volcanic origin, whereas others are intrusive masses, as indicated by cross-cutting relations in both plan and section. Many dikes are so nearly concordant, however, that their age relations are not readily determined, especially in areas of intricate folding and shearing. As some of them have been deformed in the same manner as the enclosing rocks, and to comparable degrees, they appear to antedate all the principal periods of tectonic activity. Most, however, plainly transect some folds but are themselves folded and sheared as a result of subsequent 


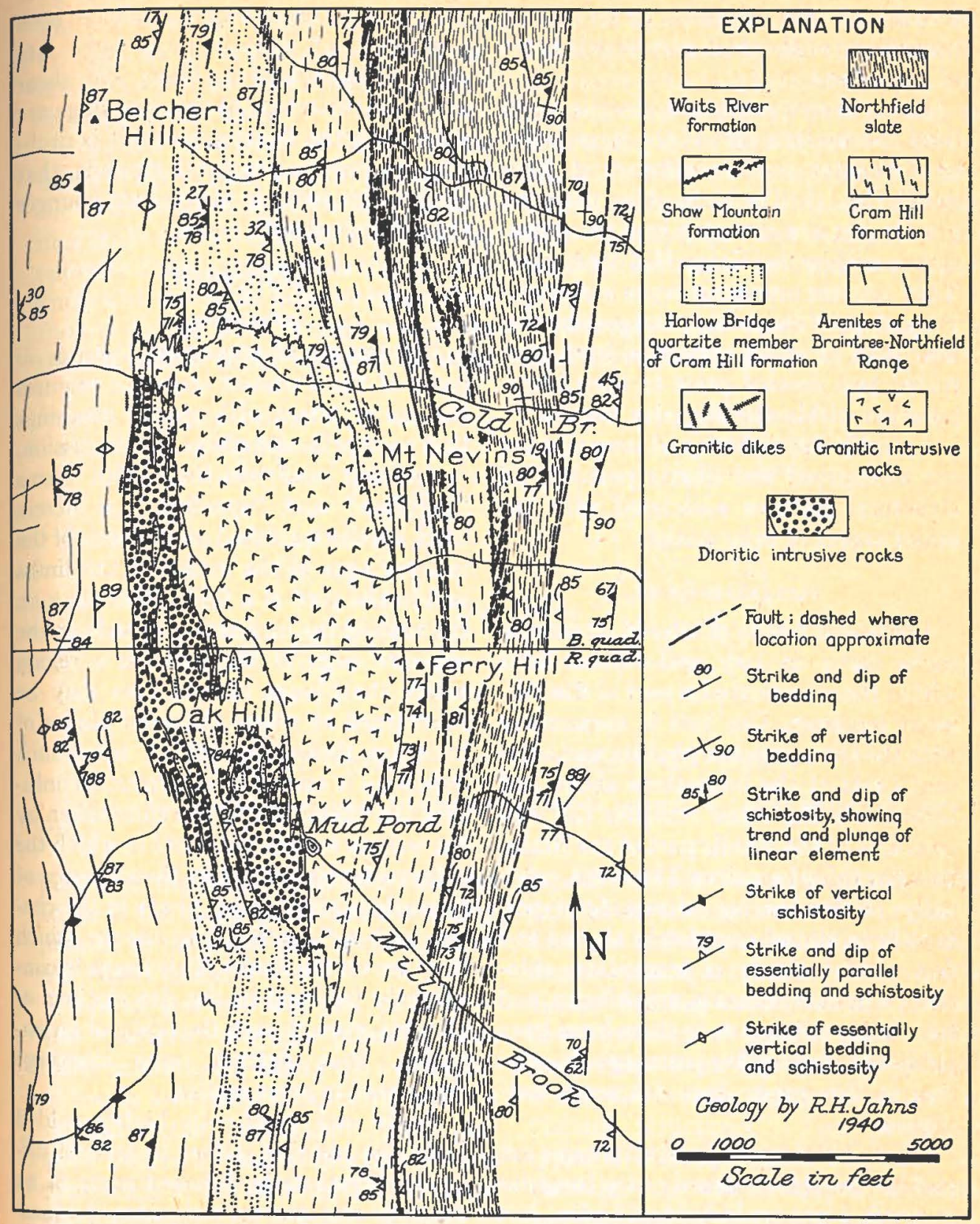

Fig. 4.-Geologic map of the Oak Hill area, north-northwest of Randolph. Boundary between Barre and Randolph quadrangles shown by horizontal line. 
deformation. This is particularly characteristic of the thickest cross-cutting masses and of the most porphyritic types of greenstone.

Fine- to coarse-grained dioritic rocks form the western part of the large intrusive complex north-northwest of Randolph (fig. 4). They are older than the granite but are intrusive into the greenstones within the Cram Hill formation. They contain numerous septa and inclusions of quartzite, schist, and greenstone, nearly all of which appear to have been folded and sheared prior to their incorporation within the intrusive masses.

Late dikes of diabase and lamprophyre are widespread and clearly postdate all structural features associated with the major stages of deformation.

\section{ULTRAMAFIC ROCKS}

Lenticular bodies of altered ultramafic rocks occur in two well-defined belts within the noncalcareous part of the Vermont sequence. One belt is coextensive with the Ottauquechee phyllite and adjacent parts of the formations above and below, and the other occupies the outcrop area of the middle part of the Braintree-Northfield arenites. The rocks, originally olivine-bearing ultramafic types, have been almost completely altered and now consist chiefly of serpentine, chlorite, carbonate minerals, amphiboles, and talc. Many references to them have been published, and further petrologic description in this paper does not seem warranted.

Most of the serpentine-rich masses are podlike, though commonly very irregular in detail. Some are individual bodies, but many appear to be connected along specific horizons in the country rock. They contain inclusions of wall rock that evidently was folded tightly prior to emplacement of the ultramafic material, but the shapes, attitudes, and distribution of the intrusive masses appear to have been controlled, at least in part, by a late stage of deformation. Folds and shear zones characteristic of this late stage are older than the Barre granite; it is probable, on purely structural grounds, that the granitic rocks in general are younger than the ultramafic rocks.

\section{STRUCTURE}

TERMINOLOGY

Description of structural features in rocks of the Vermont sequence requires the use of terms with special meanings that need prior definition and discussion.

Anticline and syncline.-The terms "anticline" and "syncline," as herein used, are distinguished on the basis of the relative ages of the rocks on the limbs and in the core of a fold rather than on the basis of the inclination of beds on the opposite sides of the fold. In a region where the plunge of fold axes may be overturned or where the axial planes of folds are themselves folded, some such definition is essential to eliminate confusion. An "anticline" is therefore taken by the writers to indicate a fold in which the older rocks (as defined by the sequence of formations given in fig. 3 ) are in the center, and a "syncline" as one in which they are on the flanks. This usage is consistently followed in the descriptions of all folds, even though the limbs of an anticline, thus defined, may converge downward in cross section.

Strike and trend.-In highly folded rocks the bedding strikes in several different directions in different parts of an outcrop, and the only significant measurement that can be made is on the "trend" of the bedding (Balk, I936, p. 702). The "trend" of bedding, as used herein, is the strike of a plane that is tangent to the respective crests or troughs of 
the minor anticlines or synclines into which a given bed has been folded (fig. 5). Most of the bedding symbols in the eastern part of the area shown in figure 2 represent local trends.

Long and short limbs of folds.-Where minor plunging folds are not isoclinal and the trend of bedding is constant, the bedding strikes in two different directions on opposite limbs of these folds (fig. 5). The limbs with one strike must be longer than those with the other, except where the trend is normal to the strike of the axial definition, the short limb of a fold can be regarded as an offset in the course of the bedding as defined by the long limbs. As one stands on a long limb and looks along its strike, the next long limb beyond an intervening short limb appears to be offset. If it is offset to the right, the fold pattern is dextral; if to the left, sinistral. This terminology was suggested for transcurrent faults by Anderson (1942, p. 55).

Cleavage.-The term "cleavage" is used through this paper to refer to the

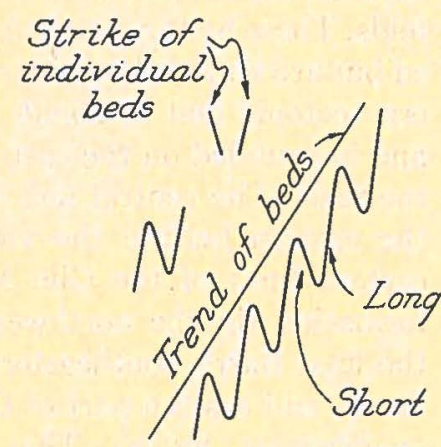

Dextral" Pattern

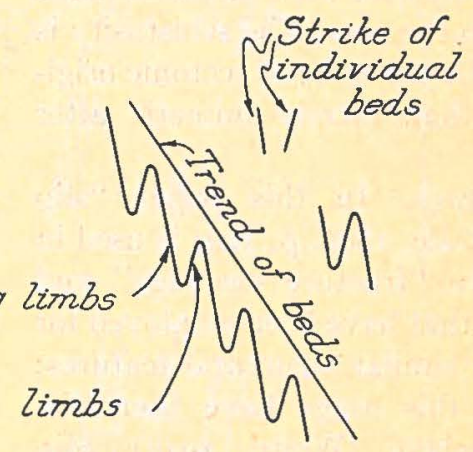

"Sinistral" Pattern text.

FIG. 5.-Idealized plans of plunging folds, showing trends, patterns, and other features discussed in

planes of the folds. It follows that the strike of the "long limbs" is more nearly parallel to the trend than is the strike of the "short limbs."

Dextral and sinistral fold patterns.The "pattern" of minor plunging folds refers herein to the zigzag trace of a folded bed in a horizontal exposure, unless a vertical section is specified. These patterns ordinarily are a function of one component of the differential movement that formed the folds, and it is useful to contrast the two possible complementary types of pattern. Each is the mirror image of the other, and the terms "dextral" and "sinistral" are used here to distinguish them (fig. 5). For the purpose of capacity of rocks to part along essentially parallel surfaces of secondary origin. It does not include parallel joints that lie a foot or more apart, nor is it here used to include bedding fissility or the primary flow structures of igneous rocks, which are perhaps more appropriately grouped under the broader terms "foliation" or "foliate structures." Two prominent types of cleavage - schistosity and slip cleavage - are well developed in central and east-central Vermont, and they are here referred to collectively as "cleavage."

Schistosity.— "Schistosity" is used here for planar cleavage that is due to mineral parallelism. The parallelism may involve 
crystallographic orientation of the micaceous minerals or dimensional orientation of nonmicaceous minerals, like quartz, feldspar, and calcite, or, most commonly, both.

Although schistosity is more or less parallel to bedding over substantial parts of the region described here, it locally transects bedding, particularly in the noses of many minor folds. In such folds the planar element, here called "schistosity," can be seen to pass gradually from parallelism with bedding on the limbs to parallelism with the axial plane of the fold in the nose. The schistosity is therefore believed to be of tectonic origigin rather than merely mimetic after bedding.

Slip cleavage.-In this paper "slip cleavage" (Dale, I899, p. 209) is used in preference to "fracture cleavage" and other terms that have been employed for the same or similar structural features; reasons for this usage have been discussed elsewhere (White, I949). Slip cleavage ordinarily comprises subparallel planes of dislocation, spaced $0.01-1$ inch or more apart. Displacement of older structures in the rock generally is apparent and measurable along these planes, and the results of displacement range from tiny, sharp flexures to small-scale faults.

Slip cleavage is distinguished from schistosity by the fact that the micas and other platy or elongate minerals between the surfaces of dislocation still preserve, wholly or in part, an orientation that antedates the development of the slip planes. The planes themselves, however, are commonly marked by concentrations of mica plates with parallel orientation.

\section{GENERAL FEATURES}

The geologic structure of the region is best described in terms of three tectonic belts, namely, eastern and western belts, characterized by nearly north strikes and approximate parallelism of geologic boundaries, and a central belt of complex folds. These belts are not sharply bounded but are nonetheless distinct. The eastern tectonic belt is about 3 miles wide and is bounded on the east by the Monroe fault. The central belt extends from the eastern belt to the vicinity of the eastern limit of the Gile Mountain (?) formation (in the northwestern part of the East Barre, southeastern part of the Barre, and eastern part of the Randolph quadrangles, fig. 2). The western tectonic belt, largest of the three, includes the western outcrop belt of the Waits River formation, as well as all formations lower in the section.

The types of geologic structure to be described belong to two major orogenic stages. The products of these two stages are most readily distinguished in the eastern and western belts, where there are two distinct types of minor fold and two types of cleavage. The folds here

FIG. 6.-Idealized plans of deformed beds, showing shapes, patterns, and attitudes characteristic of the western tectonic belt of central Vermont. $A$, gently plunging isoclinal fold-pair typical of many early flexures in slaty, phyllitic, and calcareous beds. Schistosity parallel to axial plane of folds. $B$, gently plunging open folds, typical of many early flexures in the more quartzose beds. Schistosity parallel to axial planes of folds. $C$, slip cleavage in slaty beds, with deformation of earlier schistosity. $D$, steeply plunging open fold-pair, typical of many later-stage flexures in the more quartzose beds. Earlier schistosity (not shown) is deformed. $E$, superimposition of slip cleavage and small-scale flexures with sinistral pattern and moderately steep plunge upon earlier, larger, and nearly isoclinal fold-pair. Minor folds with dextral pattern (at points $x$ and $x^{\prime}$ ) are earlier drag folds on the short limb of the nearly isoclinal fold-pair. F, gently plunging early fold, associated tight drag folds, and axial-plane schistosity bent into large, broad flexure by later-stage deformation. $G$, folded beds separated into irregular slices by faults nearly parallel to the fold axes. 

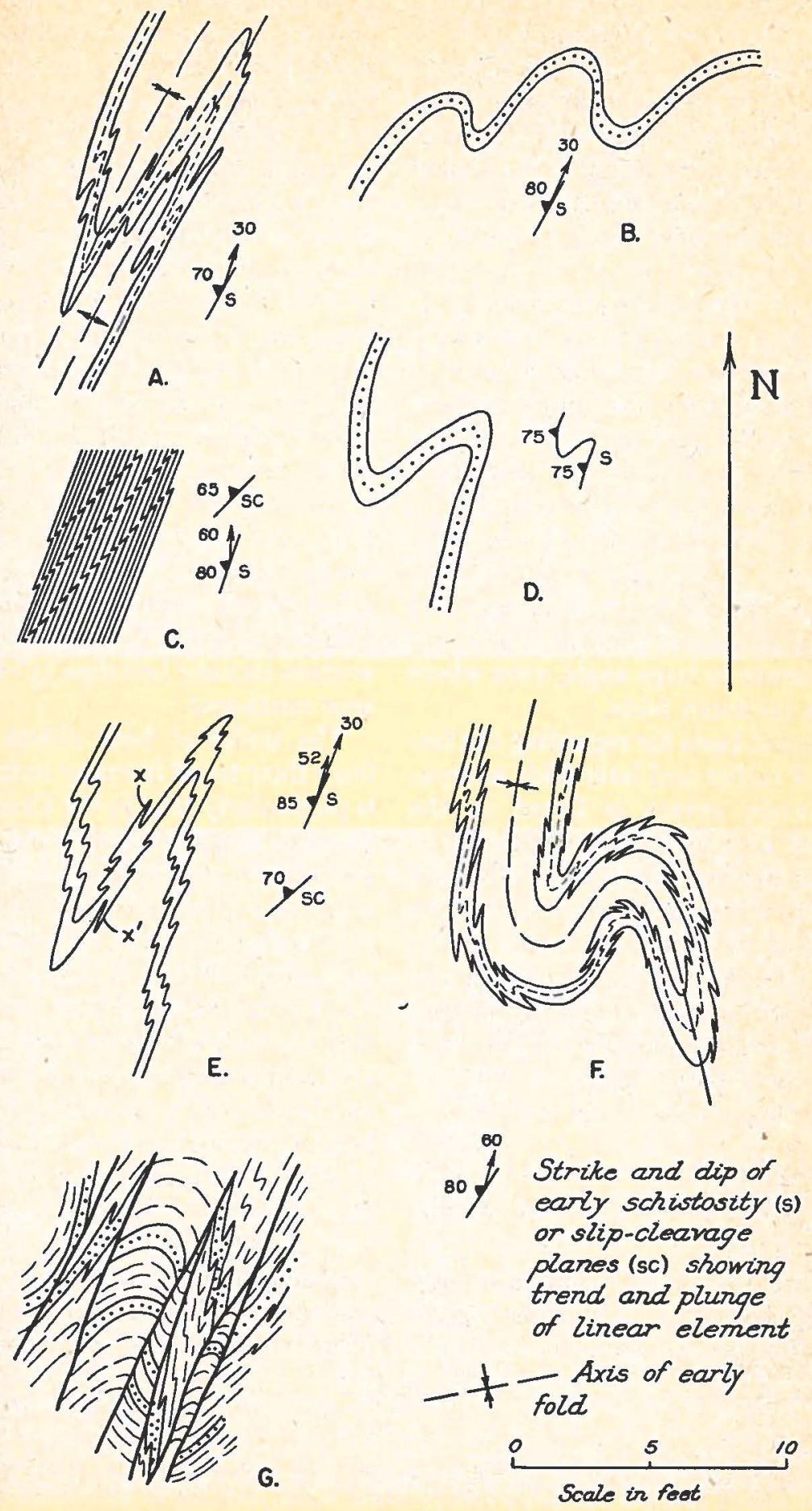

FIG. 6.-(Legend on facing page) 
called "earlier folds" are tight or isoclinal, and their axial planes are more or less parallel to the attitude of schistosity in the vicinity. On the limbs of these folds the schistosity is essentially parallel to bedding; as the bedding curves around into the nose of the fold, the schistosity transects it at higher and higher angles, and in the nose of the fold schistosity is approximately normal to bedding.

In the "later folds," in contrast to the earlier, schistosity, as well as bedding, is folded. The folds are generally more open than the earlier, and the schistosity, instead of being parallel to their axial planes, wraps around their noses. Locally, the axial plane of an earlier fold has been folded in later folds (fig. 6). Slip cleavage is parallel to the axial planes of these later folds and cuts the schistosity at a moderate to large angle, even where there are no minor folds.

Additional basis for regarding the formation of earlier and later folds as separate tectonic events is found in the plunge of axes and in the patterns of folds. As will be described below, the axes of earlier folds make a large angle with the axes of the later over much of the western tectonic belt. In the eastern tectonic belt, the plunges of earlier and later folds are similar, but the earlier have dominantly sinistral patterns and the later are almost exclusively dextral.

\section{THE WESTERN TECTONIC BELT}

Early structure.-The rocks of the western tectonic belt include nearly all units in the stratigraphic column already described. Owing to their simple gross structure and prevailingly steep dips, indi- vidual formations crop out as straight to broadly curving subparallel bands whose configuration is little affected by topography. The general structural trends are north and north-northwest in the Rochester and Randolph quadrangles, north and north-northeast in the Lincoln Mountain and Barre quadrangles. Steep easterly dips are characteristic of the bedding in the western part of the tectonic belt. These become steeper in higher parts of the section, and many of the beds are vertical where exposed in the crestal part of the Braintree-Northfield Range. Very steep westerly dips prevail in the western third of the Barre and Randolph quadrangles, and farther east the average westerly dip decreases markedly but not abruptly. Most of the bedding in the Waits River formation in the western tectonic belt dips $35^{\circ}-60^{\circ}$ west to west-northwest.

The strike of beds differs distinctly from their trend in many outcrops. This is particularly true in the Cram Hill and adjacent formations, where the trends of some beds and groups of beds are as much as $25^{\circ}$ more toward the west than most individual strikes. The average discordance, however, is probably less than $10^{\circ}$. Farther east and west the strike and trend of beds are much more nearly parallel. Schistosity is very well developed and is essentially parallel to the strike of bedding except on the crests and troughs of folds. That this concordance is not perfect on many limbs of folds as well is demonstrated by slight angular relations in slate quarry exposures near Northfield and in several large outcrops elsewhere. Moreover, the schistosity is commonly a

\section{PLATE 1}

$A$, Open fold shown by quartzitic beds in quartz-chlorite-sericite schist. Note axial-plane schistosity

$B$, Close folds in quartzite and quartz-chlorite-sericite schist. Note fanlike distribution of fractures in the quartzite beds at crests and troughs of folds. 

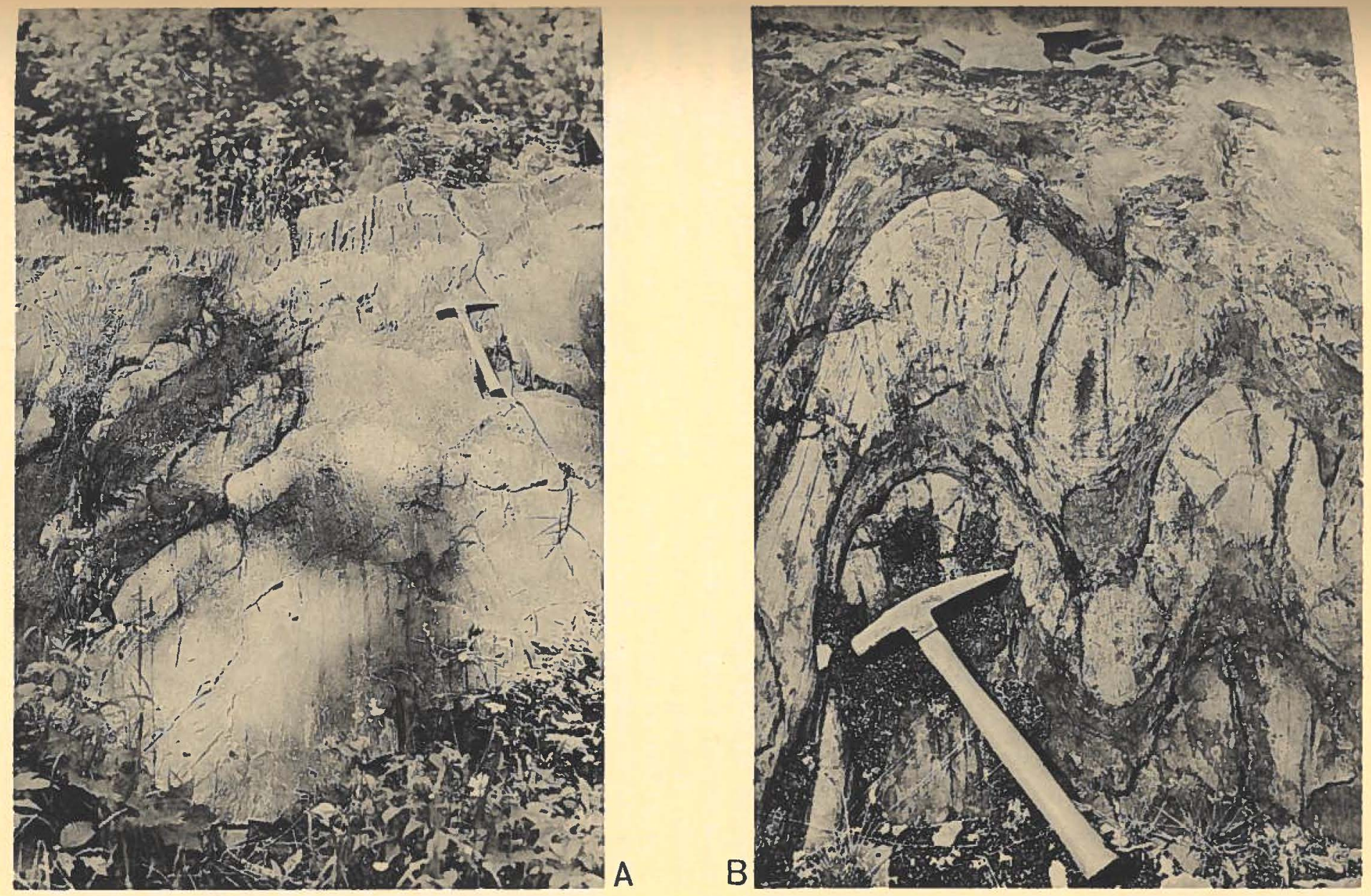

Early folds in the western tectonic belt, central Vermont. Arenites of Braintree-Northfield range 

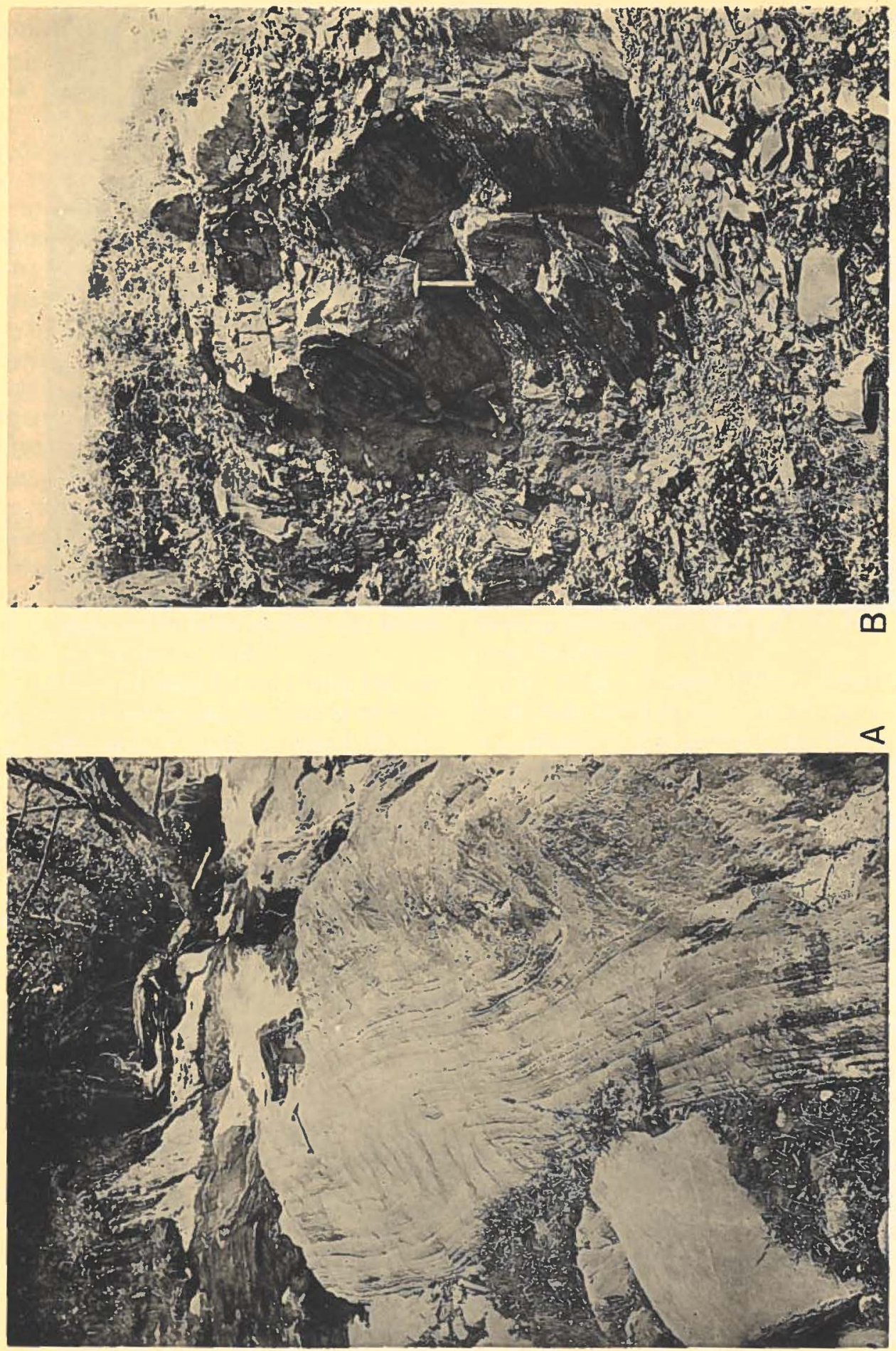
little steeper than eastward-dipping bedding and a little less steep than westward-dipping bedding. For all practical purposes in most places, however, the two features are so nearly concordant that both are represented by the bedding symbols in figure 2.

The earliest folds in the western tectonic belt vary greatly in form but are strikingly consistent in attitude and in their relation to cleavage. Most of those in the slaty, phyllitic, and uniformly schistose rocks are tightly compressed, with sharp crests and troughs and parallel or nearly parallel limbs. Folds of this type in the calcareous parts of the Waits River formation show evidence of considerable rock flowage during deformation, and the limbs of many are much attenuated. Where more competent beds are present, as in the quartzitic parts of the pre-Shaw Mountain formations, the folds are broader and more open, with gently rounded crests and troughs. All gradations between open and isoclinal folds are present, and the form of the folds evidently depends more upon the lithology of the rocks involved than upon any other single factor (pl. I).

In general, these folds are minor structures, regardless of their form, and most of them have amplitudes of only a few feet. However, they range in amplitude from an inch or less to hundreds of feet. One large, nearly isoclinal fold near the southeast corner of the Barre quadrangle is clearly outlined by a contact between calcareous and noncalcareous rocks (fig. 2). Other, somewhat smaller folds of similar form affect the strata of the Shaw
Mountain formation (fig. 7); doubtless, more are present in areas where there are no marker beds to permit their easy recognition. Open to moderately tight folds of considerable size occur in the lower part of the Waits River formation, especially in the area east and northeast of Northfield. The largest of these flexures, in the north-central part of the Barre quadrangle, is about $I, 700$ feet wide. Even in this area, however, nearly all the early folds are too small to be shown on ordinary quadrangle maps.

Schistosity (slaty cleavage in slates) is parallel to the axial planes of the early folds in the noses of these folds, and a fracture cleavage that dips toward these axial planes in anticlines and away from them in synclines is present in some beds of quartzite and other relatively competent rocks. Such beds are commonly cut by fanlike groups of fractures along their crests or troughs (pl. I, $B$ ). Gentle and moderate plunges are most characteristic of the folds, regardless of their tightness. As shown by observed crests and troughs, by the intersection of bedding and foliation planes, and by the attitude of minor crenulations, most plunges are north at angles of $10^{\circ}-55^{\circ}$. Steeper inclinations are rather rare, and the average plunge is about $30^{\circ}$. Gentler plunges are more common, and horizontal or southwardly inclined fold axes occur locally.

The north-plunging early folds have a sinistral pattern in plan. At some places, generally where the plunge of the folds is southward, the pattern is dextral in plan. As viewed from the south in an

\section{PLATE 2}

$A$, Sharp early fold in quartzitic schist near base of Cram Hill formation. Bedding is folded, with schistosity essentially parallel to the long limbs of folds. Both bedding and schistosity are transected by slip cleavage.

$B$, Broad flexure in phyllite and schist of Waits River formation, with strongly developed slip cleavage. 


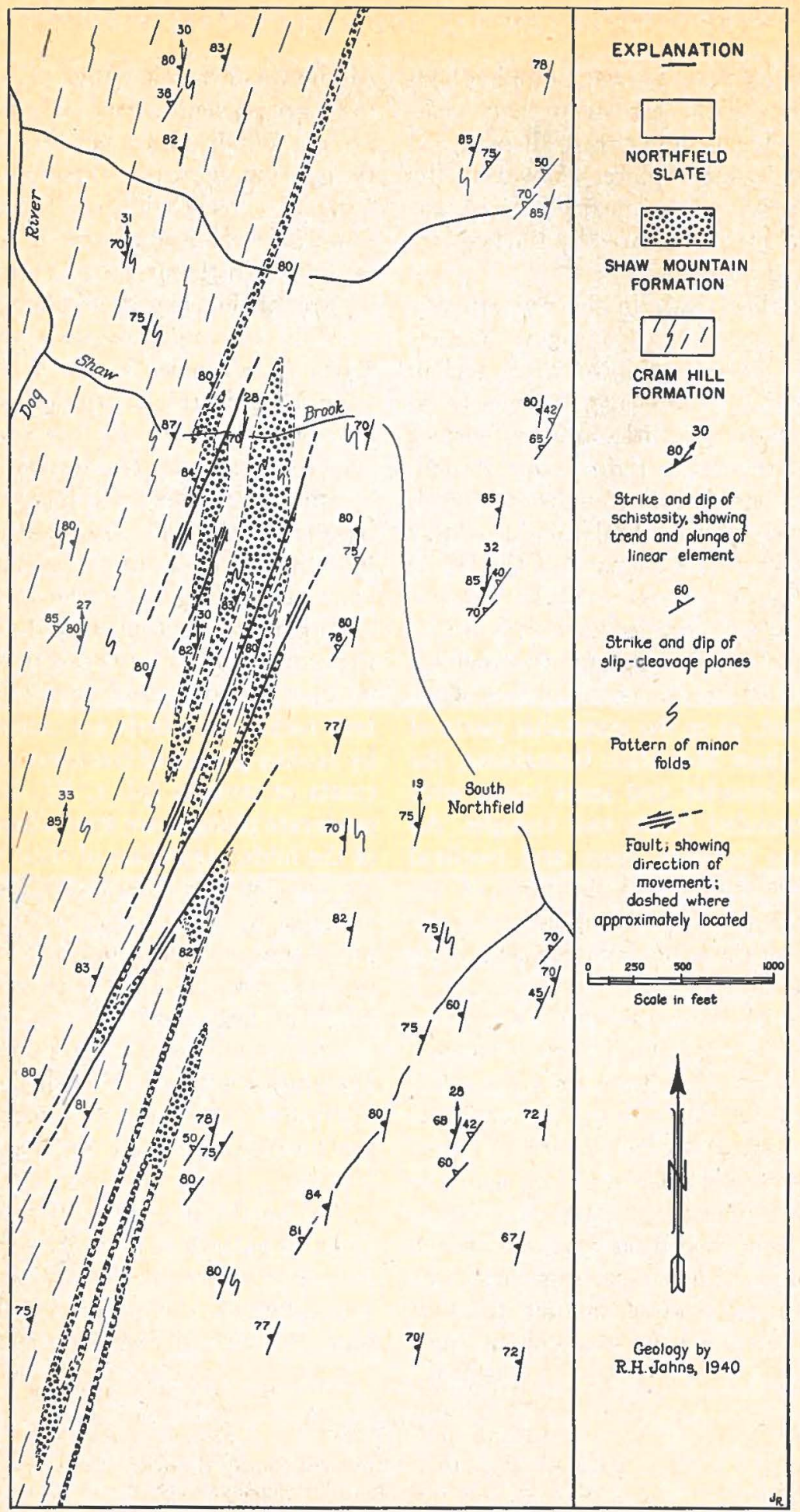

Frg. 7.-Geologic map of the South Northfield area, Barre quadrangle 
east-west vertical section, therefore, the typical pattern of almost all these early folds is sinistral and indicates that the rocks on the east moved upward with respect to those on the west.

The known succession of progressively younger beds from west to east in central Vermont is entirely compatible with the interpretation of the prevailing fold pattern as the result of drag on the east limb of a very large anticline or archlike structure whose axis lies west of the area herein discussed. According to W. M. Cady (oral communication, I948), the existence of such a major anticline appears to be demonstrable in the latitude of central Vermont, where its axis lies about 3 miles east of Bolton, and in the latitude of Rutland, where its axis lies on East Mountain, in Mendon. Evidence of it is convincing in several areas farther north along the strike. In the Sutton Mountains of southern Quebec, for example, a broad anticlinal structure has been described by Fairbairn (1932, pp. 7I-75), Clark (1934, p. I5), and Ambrose (1942).

Later structure.-Superimposed on the structural pattern of the earlier folds are later structural features that include slipcleavage planes, folds, faults, and thin shear zones. A pronounced slip cleavage is widespread and is most common in the slaty and phyllitic parts of the terrane. Both bedding and the schistosity previously described are cut by this slip cleavage. In general, its degree of development increases from north to south and from west to east, although there are many local irregularities. In phyllites and slates the slip cleavage is so intensely developed south of the latitude of Randolph that closely spaced series of corrugations form the most conspicuous feature of the rock fabric. This structure characterizes the so-called "fence-post phyllites" used by many farmers in the
Randolph and Rochester quadrangles. Some of the rocks farther south and east are so severely deformed that all traces of their earlier schistosity have been obliterated by very closely spaced cleavage planes, which themselves constitute a crudely developed schistosity in many areas.

The slip-cleavage planes typically strike $10^{\circ}-50^{\circ}$ more to the east than does the schistosity of the early stage of deformation, and they dip a little less steeply west where the dip of the schistosity is westward or vertical. They dip very steeply in parts of the section beneath the Cram Hill formation and in such places intersect the planes of schistosity along steeply inclined lines that contrast markedly with the more gently dipping linear elements associated wholly with early-stage deformation. Farther east, however, the slip-cleavage planes dip progressively less steeply, and they tend to merge in attitude with the more gently dipping cleavage of the Northfield slate and the Waits River formation. The average number of cleavage planes per unit of rock exposure and the closeness of spacing of these planes also increase toward the east.

Minor folds in the earlier schistosity are here classed as later folds. Where slip cleavage is present, it is parallel to the axial planes of these folds, and displacements along slip-cleavage planes are responsible, in part, for the present shapes of many of the late folds. The relation between displacements on cleavage planes and such late folding is most evident where competent beds are involved, because in many of the more incompetent rocks bedding and the earlier schistosity are all but obliterated by closely spaced slip-cleavage planes. Essential contemporaneity of the later minor folds and the slip cleavage is suggested by two lines of 
evidence: the slip cleavage is parallel with the axial planes of such minor folds, and the folds are generally more abundant and more acute where slip cleavage is most intensely developed.

Like the slip-cleavage planes, the later folds are superimposed on the flanks of earlier flexures and locally involve entire isoclinal folds (fig. 6). They have sharp crests and troughs, like the isoclinal type of earlier folds, but typically are much more open ( $\mathrm{pl}$. 2, B). One flank generally is very short, and a sinistral pattern is characteristic of all areas except those within and west of the Braintree-Northfield Range, Barre, and Lincoln Mountain quadrangles (fig. 2). With their prevailingly steep north plunges in the central part of the western tectonic belt, these folds indicate a northward displacement of rocks on the east with respect to those on the west or a horizontal shearing movement similar to that adduced by Hawkes (I94I, pp. 657-658) to account for steep linear structure near Bridgewater, Vermont. Farther east, where their plunges become more gentle, the folds also demonstrate an upward movement of rocks on the east with respect to those on the west. It should be noted that both the earlier and the later minor folds in most of the western tectonic belt have the same prevailing sinistral pattern. Dextral patterns in the late folds are common only in the western part of the belt.

The pebbles of the quartz conglomerate in the Shaw Mountain formation have been drawn into long ellipsoids by tectonic action and in places appear to be at least four times as long as they were when deposited (Currier and Jahns, I94I, p. I497 and pl. 2). The long axes of these stretched fragments plunge gently to steeply northward and ordinarily reflect deformation during the earlier of the two principal stages discussed above. A similar orientation is characteristic of many rows of biotite, garnet, and hornblende porphyroblasts. The conglomerate pebbles are severely cracked, fractured, or otherwise deformed, whereas very few of the porphyroblasts are. The latter, therefore, must have been developed no earlier than the last stages of the deformation.

Movement during both stages of deformation also is thought to have been responsible for much of the erratic distribution of quartz conglomerate and other very competent beds in the Shaw Mountain formation. The thicknesses of these beds differ greatly within short distances, and, according to Currier and Jahns (I94I, p. I499), "because of these abrupt changes, as well as the abundant evidence of shearing in the beds, the irregular, podlike distribution of the conglomerate is attributed to tectonic forces rather than to variations in original sedimentation." The gentle to steep plunges of elongate pebbles in the conglomerate and of several of the podlike masses themselves is parallel to the plunge of earlier minor folds in the vicinity; this suggests that this deformation was accomplished chiefly by tectonic forces of the earlier, rather than the later, stage.

Well-defined faults and shear zones are superimposed on earlier structural features in many places. These shear zones either are intermediate in orientation between the earlier schistosity and the later slip-cleavage planes or are parallel to the slip-cleavageplanes. Asa result, many outcrops show the noses of folds but little of their flanks, or at least of flanks that can be specifically correlated with individual noses. Displacements along the faults rarely are measurable but, in general, probably are not great. A few exceptional 
faults, however, have offset large folds a mile or more, particularly in the lower part of the Waits River formation. A poorly defined fault that appears to displace a contact between the Northfield slate and the Waits River formation are marked by dextral patterns in plan, by moving additional folds into each group. This process of "thickening" is shown diagrammatically in figure 8.

Many thrust faults and open joints transect all the above-described struc-
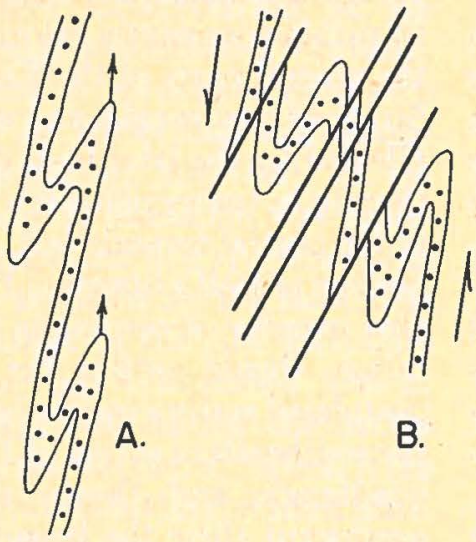

A.

B.

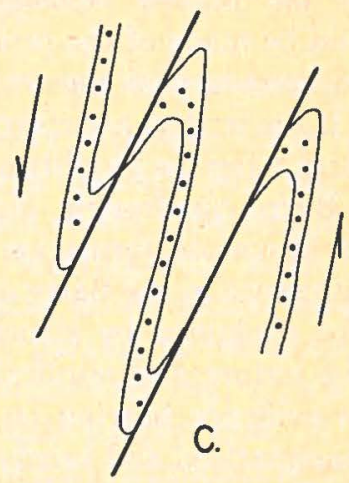

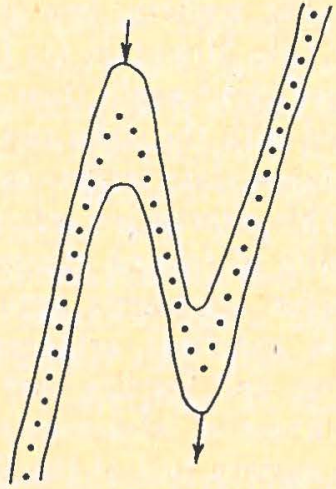

D.

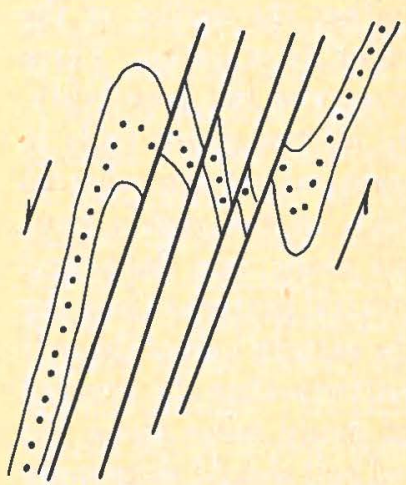

E.

FIG. 8.-Idealized plans of folded beds, showing "thickening" by late-stage shear movements. $A$, northplunging folds with sinistral pattern. $B$, "thickening" of the fold group by means of shear faults that transect the long limbs. $C$, somewhat different "thickening" by means of shear faults that transect the short limbs. $D$, south-plunging fold-pair with dextral pattern. $E$, slight "thickening" by means of shear faults that transect the short limb of fold-pair with dextral pattern.

(fig. 2) may represent this longitudinal type.

Shearing and minor faulting have "thickened" many groups of earlier folds with sinistral patterns, as well as some groups of southward-plunging folds that tural features in the western tectonic belt. These trend northeast to east and dip northwest to north at moderate angles. All appear to reflect a regional overriding from the northwest and north, but the magnitude of this defor- 
mation is not great. A still later chapter in the tectonic history of the region is represented by steeply dipping joints that trend east. Many of these are filled with diabasic and lamprophyric dikes.

Problem of the eastern boundary.Mention should be made of the problem of the eastern boundary of the western tectonic belt. If the writers are correct in tentatively correlating the phyllite of the southeastern Barre quadrangle (fig. 2) with the Gile Mountain formation farther east, its presence in the Barre quadrangle must be explained by structural repetition. The nature and implications of the known evidence bearing on this problem are summarized and briefly discussed in the following paragraphs.

I. The belt of the Gile Mountain (?) formation in the Barre quadrangle might be viewed as the axial part of a syncline formed during either the earlier or the later stage of major deformation. Three lines of evidence oppose this possibility. First, practically all the minor folds in this belt have a sinistral pattern, whereas known major folds in the region have sinistral patterns along one flank and predominantly dextral patterns along the other. Second, the eastern half of the belt is much more quartzose than the western for a distance of many miles along the strike. A synclinal belt should show more symmetrical distribution of more and less quartzose phyllite on opposite sides of the main fold, unless sedimentary facies changes are exceptionally rapid. Third, although most of the earlier and later minor folds plunge north at appreciable angles, the belt as a whole does not narrow to the south as it should if it were a major syncline plunging north, parallel to the minor folds.

2. The Gile Mountain (?) formation of the Barre and Randolph quadrangles might represent the western $\operatorname{limb}$ of a huge, north-plunging syncline, the corresponding unit on the eastern limb of which would be the Gile Mountain formation of the Strafford, Mount Cube, and Woodsville quadrangles (figs. 2 and I 2, B). The axial part of this fold would lie within dominantly calcareous rocks in the central parts of the East Barre and Strafford quadrangles and would be complicated by the later folds described farther on in connection with the structure of the central tectonic belt. Rocks at the horizon of Doll's Standing Pond amphibolite member, according to this interpretation, should outline the nose of the postulated major syncline in an area near the southeastern corner of the Randolph quadrangle and thence should trend northward along the boundary between the Gile Mountain (?) formation and the Waits River formation fo the west (fig. 2). The western, less quartzose part of the Gile Mountain (?) formation in the Barre quadrangle then might be correlated with the slaty and phyllitic Meetinghouse slate farther east.

This alternative interpretation of the results of folding eliminates the stratigraphic arguments against the smallerscale synclinal arrangement described above and implies that a considerable thickness of calcareous rocks - shown as the eastern belt of the Waits River formation in figure 2-must lie stratigraphically above the Gile Mountain formation. No rocks that appear to be the equivalent of the Standing Pond amphibolite member are present along the eastern margin of the Gile Mountain (?) formation in the Barre and East Barre quadrangles, but this amphibolite is not continuous even in the Strafford quadrangle. The most serious argument against the major-fold interpretation is the dominant occurrence of sinistral pat- 
terns in the early-stage folds of the eastern tectonic belt.

3. Repetition of the formations by a strike fault at or near the eastern boundary of the Gile Mountain (?) formation (see fig. $12, A$ ) is in many respects the most attractive interpretation, in the light of currently available field evidence. The formations on opposite sides of such a fault may be homoclinal and simply brought together by the fault, or the Gile Mountain (?) formation may represent the western limb of a syncline whose eastern limb is cut off by the fault. The eastern boundary of the Gile Mountain (?) formation was compressed into at least one tight fold during the earlier stage of deformation (fig. 2); hence, if the fault follows this boundary, it must antedate most or all of the earlier stage of deformation. There is no evidence elsewhere in this region for a stage of faulting earlier than the earlier folding. This boundary, furthermore, is locally gradational and not so sharp as it should be if due to a fault. For these reasons it is unlikely that a fault lies exactly on the boundary. The strike fault, if it exists, probably lies somewhat farther east; thus it is necessary to assume at least a limited amount of calcareous rock above the Gile Mountain (?) formation, as shown in figure 3 .

Although a fault of the type postulated above would best harmonize the known structural and stratigraphic relations of the rocks involved in this discussion, there is no positive evidence for such a fault. Detailed mapping in the eastern part of the Randolph quadrangle is needed as a basis for choosing between the interpretation of the broad fold and that of the major fault. Indeed, it is needed fully to test the equivalence of the Gile Mountain formation and the unit tentatively correlated with it. If there is no such equivalence, the Gile Mountain (?) unit may well be simply a thick, noncalcareous member of the Waits River formation. The stratigraphic section, under these conditions, would be enormously thicker than postulated above.

\section{THE EASTERN TECTONIC BELT}

Early structure.-The rocks of the eastern tectonic belt are phyllites and schists of the Gile Mountain formation and Meetinghouse slate. The strike of bedding in individual outcrops is essentially parallel to the trend of the Meetinghouse slate (fig. 2), and the dips are vertical, steeply east, or steeply. west. Schistosity, a product of the earlier stage of deformation, is essentially parallel to bedding, and its prevailing attitude is indicated by the symbols for bedding in figure 2. Intersection of bedding and schistosity at low angles is evident locally but is not characteristic.

Minor isoclinal folds with schistosity parallel to their axial planes are exposed in some areas. In the Woodsville quadrangle these folds plunge $5^{\circ}-60^{\circ}$ in a northerly direction, with an average of about $32^{\circ}$. They generally have a sinistral pattern when viewed in plan or northward in section. This pattern is shown by eleven out of fifteen observed folds in the Woodsville quadrangle. In the Vermont portion of the Littleton quadrangle, farther northeast along the same structural belt, J. H. Eric (personal communication) noted that thirteen out of fifteen folds were of the same type. This prevailing pattern, which also is characteristic of the earlier folds in the western tectonic belt, indicates that rocks on the east were moved upward with respect to rocks on the west during the earlier stage of deformation. Interpreted as drag folds, they indicate that the rocks on the 
west are older than those on the east. Their priority in the sequence of tectonic events makes these earlier folds much more reliable for such interpretations than those of the later stage.

In the northern part of the Woodsville quadrangle, the contact between the Waits River and Gile Mountain formations is doubled back to form a $\mathrm{V}$ pointing north and outlines a fold of sufficient size to be shown in figure 2. The axial plane of the fold strikes about N. $30^{\circ} \mathrm{E}$., essentially parallel to the schistosity of the earlier stage of deformation; it is intersected at high angles by the slip cleavage of the later stage, which here strikes N. $25^{\circ}-45^{\circ} \mathrm{W}$. The fold, which consists of an anticline partly cut off on its western limb by a fault, is therefore interpreted as a product of the earlier stage of deformation. It is the only large fold in the eastern tectonic belt that represents this stage.

Later structure.-Slip cleavage is characteristic of the later-stage deformation in the eastern tectonic belt, and its attitude is shown by the cleavage symbols in figure 2 . It is poorly developed and locally nonexistent in the eastern part of the belt, but farther west it is the dominant feature of the rock fabric. In the western part of the belt the cleavage planes are so closely spaced that in many places the identity of individual planes is only apparent under the microscope. This slip cleavage grades into the schistosity of the central tectonic belt without any abrupt change in orientation. It is characterized by northward strikes and eastward dips of $20^{\circ}-70^{\circ}$. The average dip is less in the western part of the belt than in the eastern part.

Both bedding and the earlier schistosity are deformed in the minor folds of the later stage. The axial planes of these folds are parallel to the later slip cleav- age, and the folds plunge northward at angles that commonly range from $15^{\circ}$ to $55^{\circ}$. The average plunge of fold axes increases from south to north in the belt. The later minor folds generally have a dextral pattern, and very few exceptions were noted among many hundreds of observations. This pattern indicates a differential movement in which rocks on the west rose with respect to rocks on the east, the reverse of the movement indicated by the pattern of the earlier folds. The number of later minor folds per unit area of outcrop increases westward in the belt, and the average acute angle between adjacent limbs of individual folds decreases in the same direction.

Comparison with western tectonic belt.The structural features of the eastern tectonic belt should be briefly compared with those of the western belt as a prelude to description of the central tectonic belt. In both eastern and western belts the earlier minor folds are predominantly sinistral in plan and plunge gently to fairly steeply northward. The later minor folds in the eastern belt plunge more or less parallel to the earlier folds, but, being dominantly dextral, differ from the earlier in pattern. In most of the western tectonic belt, on the other hand, both earlier and later minor folds have the same sinistral pattern, although over wide areas these folds differ distinctly in plunge. Finally, the intensity of the later stage of deformation, roughly paralleled by intensity of thermal metamorphism, increases westward in the eastern belt and eastward in the western.

These facts suggest that the effects of the earlier stage of deformation were relatively uniform over the entire region. During the later stage, on the other hand, the intensity of deformation and thermal metamorphism increased toward a maximum somewhere in the central 
tectonic belt. Furthermore, the rocks of the central tectonic belt rose with respect to those on either side, as shown by the patterns of the later minor folds.

\section{THE CENTRAL TECTONIC BELT}

The dominant structural feature of the central tectonic belt is a broad cleavage arch that hitherto has been regarded as an ordinary anticline (E. Hitchcock, 186r, p. 254; C. H. Hitchcock, I91 2 ; Doll, 1945, p. 22). It is more than Io miles wide, with an axial plane that trends nearly north and probably dips more or less vertically. The arch can be traced far beyond the northern and southern limits of the area described in this paper. Demonstration of the true nature of this arch, which the writers do not regard as a simple anticline, is the chief purpose of the following discussion.

Cleavage, bedding, and folds.-The principal cleavage of the central tectonic belt is a schistosity that was formed during the later of the two principal stages of deformation recognized in the region. Several lines of evidence lead to this conclusion.

The schistosity of the central belt, traced eastward, merges in attitude with the slip cleavage of the eastern tectonic belt and makes a high angle with the earlier-stage schistosity there. Further, the slip-cleavage planes of the eastern belt become more and more closely spaced toward the west and seem to grade into a schistosity as the septa between slip planes becomes less and less distinct (White, I949, pp. 590-59I); the schistosity so formed is the characteristic cleavage of the central belt. Finally, traces of an earlier schistosity wrap around the noses of some minor folds in the more quartzose beds of the central tectonic belt.

A different type of evidence concerns the relation of cleavage to thermal metamorphism. The slip cleavage of the eastern tectonic belt was formed before the peak of thermal metamorphism in that belt, as shown by countless unbroken porphyroblasts that lie across slip-cleavage planes. The schistosity of the central tectonic belt, on the other hand, is later than, or at least as old as, a considerable amount of the thermal metamorphism; many porphyroblasts are broken, and the schistosity tends to wrap around them. The porphyroblasts of the central tectonic belt cannot be vastly different in age from those of the eastern belt, inasmuch as both fit a uniform pattern of metamorphism increasing in intensity toward the west. The apparent discrepancy in their relation to deformation in the two belts may be explained on the basis that the porphyroblasts were not strictly contemporaneous everywhere but began to form slightly earlier in the area that was ultimately most highly metamorphosed. In any case, the main point of this argument is that the schistosity of the central belt, which is, at least partly, later than the associated porphyroblasts, may be contemporaneous with, but is certainly no older than, the pre-porphyroblastic slip cleavage of the eastern belt.

In the eastern belt and in the eastern part of the central belt, the later cleavage (slip cleavage or schistosity) strikes northwest and dips northeast, whereas in the western belt and western part of the central belt, it strikes northeast and dips northwest (fig. 2). In the middle of the central belt, along a line that trends nearly north through the middle of the Strafford and East Barre quadrangles, the schistosity strikes east and generally dips $10^{\circ}-30^{\circ}$ north, but in the southernmost part of the Strafford quadrangle it dips about $45^{\circ}$ south. These attitudes 
define the arch, which plunges gently northward over most of the area and rather steeply southward in the southernmost part. The southern part of the Strafford quadrangle, therefore, contains a doubly plunging arch, or dome, in the schistosity; this schistosity, as stated above, is a product of the later stage of deformation.

The bedding in the rocks of the central tectonic belt is subparallel to this later schistosity in detail and is highly divergent from it in larger-scale trends. The contact between the Waits River and Gile Mountain formations (fig. 2) best reveals these trends and hence the true nature of the geologic structure. On the eastern side of the cleavage arch, this formation boundary trends nearly north through most of the Woodsville quadrangle and thus parallels the strike of the rocks in the eastern tectonic belt. Near the southern boundary of the quadrangle, however, the contact bends abruptly westward, and the bedding of the rocks along it is highly folded. Most of these folds are too small to be shown in figure 2. Both the folds and the major bend belong to the later stage of deformation, as shown by their axial planes, which strike northwest in conformity with the slip-cleavage planes in areas farther east, and by the fact that the earlier schistosity is wrapped around the noses of the minor folds.

These later folds are larger and more nearly isoclinal in the southeastern part of the East Barre quadrangle, and in the northern part of the Strafford quadrangle limbs of individual folds - as measured in a single bed - are as much as 3 miles long. The axial planes of these folds, as well as those of the minor folds on their flanks, are parallel to the schistosity that defines the major arch, and the folds typically plunge north-northeast or northeast.
Their axes make a moderate to large angle with the crestal line of the cleavage arch.

Structure of the Strafford Village area. -The relation of the large, nearly isoclinal folds to the cleavage arch is best shown in the vicinity of Strafford Village (fig. 9). The rocks in this area belong to the Waits River and Gile Mountain formations. The Standing Pond amphibolite member of Doll, which lies at or near the top of the Waits River formation, forms an excellent marker horizon by means of which the geologic structure of the area can be clearly outlined.

The crestal line of the cleavage arch divides the Strafford Village area into an eastern and a western flank. It trends nearly north in most of east-central Vermont, but west of Strafford Village it trends northwest for a short distance. Four large isoclinal or nearly isoclinal folds are apparent from the outcrop pattern of the Standing Pond amphibolite member on the eastern flank of the arch. These are named, from northeast to southwest, the Orange anticline, the Old City syncline, the Grannyhand anticline, and the Strafford Village syncline (fig. Io). Each of these folds has specific characteristics.

The Orange anticline ( $O$ in fig. Io) is a $V$-shaped fold, whose limbs meet in plan at an angle of about $60^{\circ}$. The bedding on the southwest limb is essentially parallel to schistosity, but on the northeast limb these two planar elements are markedly divergent. The average plunge of minor folds in the vicinity of the nose of this fold is $25^{\circ}$ north-northeast.

The Old City syncline ( $C$ in fig. Io) is relatively open, with prominent secondary folds on its rather blunt nose. The average plunge of these minor folds is $35^{\circ}$ north-northeast. The outcrop of Doll's Standing Pond amphibolite mem- 


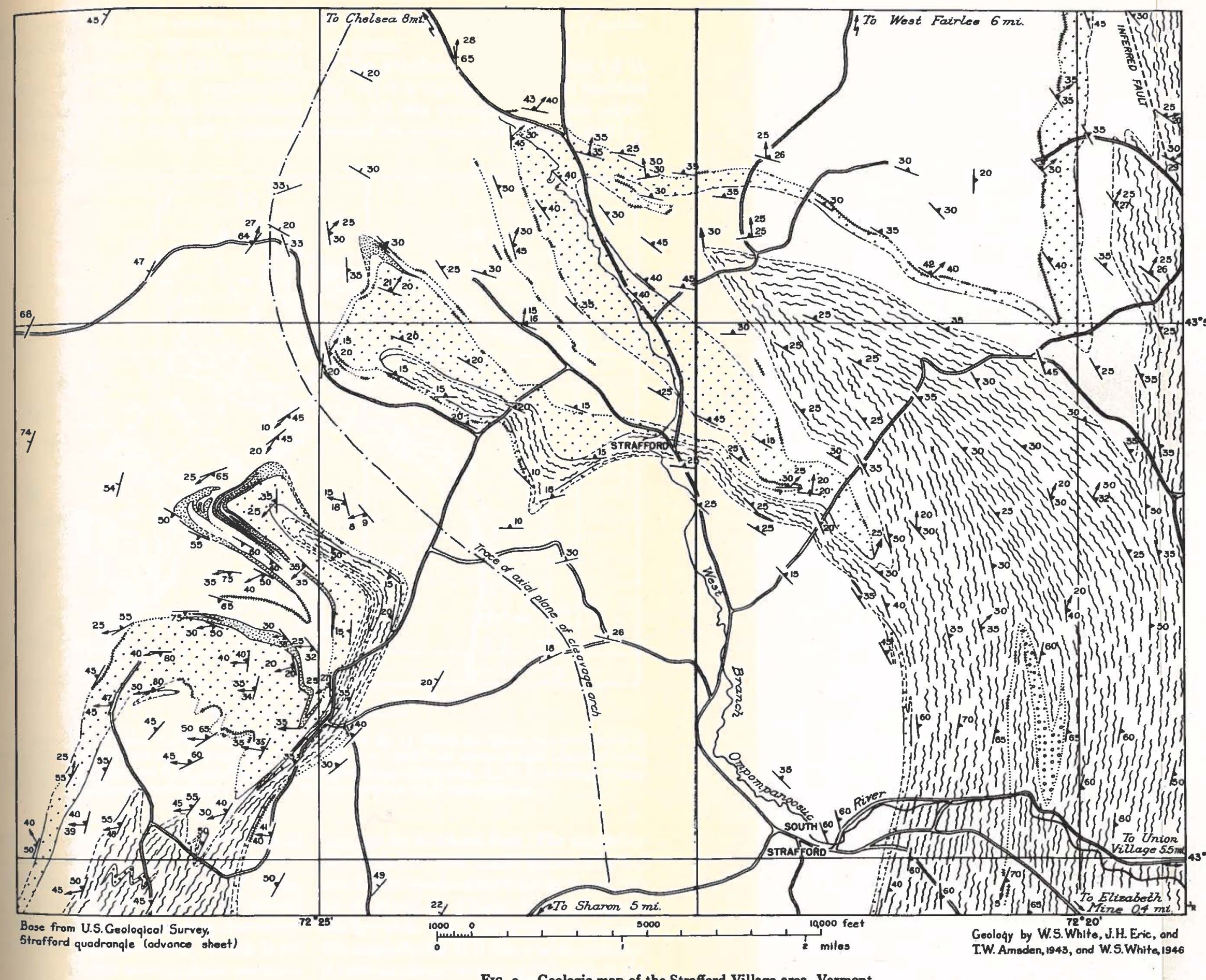

EXPLANATION LITHOLOGIC UNITS

[द्यु级

GLE MOUNTAIN FORMATION

Quartz-mioa schist, micaceous

蕰:

GLE AMPHIBOLITE IN

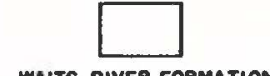

CelcaIVEA FORMATION

impure marklea sehto

quartz-mica schist

STAMDING POMD AMPMIBOLITE (DOA) Flow or sull, near or at top

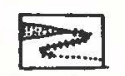

COARSE GARMET SCHIST

In both Gilo Mourtain and

dotted lune where prosenco

of this rock inferred

SYMBOLS

Lithologic boundary,
occurotely locoted

uthologle boundary

location inferred

Trace of exial plone

of cleavage arch

25

Strike and dip of

schistaibity 25

Projected strike and

plunge of fold axis 20

Strike and dip of schistosity, with plunge of intersection of schistosity and bedding. Where minor folds ore . Present their oxes are
porallel to this intersection

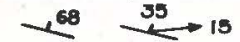

Strike ond dip of bedding of fold axes from poungo Doll (24th Rept. V. Stote Geol., (945)

Fig. 9. - Geologic map of the Strafford Village area, Vermont 
ber is very broad on the southern limb of this syncline, which is the northern limb of the Grannyhand anticline. Several hundred feet below the amphibolite, near the axial plane of the Grannyhand anticline, there is a thin and persistent of minor folds near this nose is $25^{\circ}$ northnortheast.

The Strafford Village syncline ( $A$ in fig. Io) is a tightly compressed isoclinal fold. All the stratigraphic units represented are considerably thinned, particu-

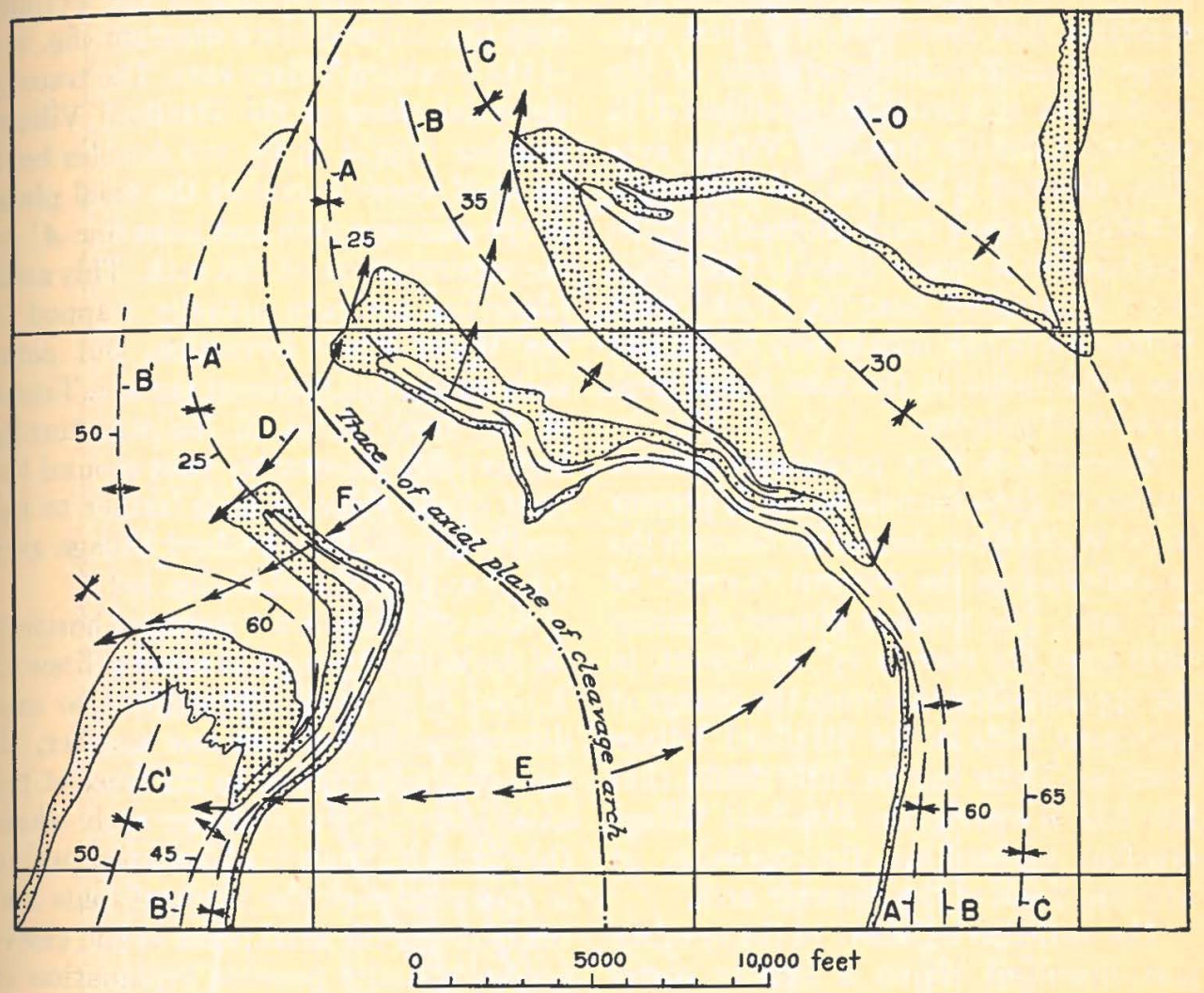

Fig. I0.-Tectonic map of the Strafford Village area (see fig. 9). Folds are shown by distribution of Standing Pond amphibolite of Doll (stippled). $A, A^{\prime}, B, B^{\prime}, C, C^{\prime}$, and $O$ are traces of axial planes of folds, with dips also indicated; and $D, E$, and $F$ are horizontal projections of fold axes, $A, A^{\prime}, D$, Strafford Village syncline; $B, B^{\prime}, E$, Grannyhand anticline; $C, C^{\prime}, F$, Old City syncline; $O$, Orange anticline.

horizon of coarse garnetiferous schist in the Waits River formation.

The Grannyhand anticline ( $B$ in fig. Io) is a moderately attenuated, almost isoclinal, fold. Its outstanding characteristic is a very pointed nose, which is reflected by all the stratigraphic contacts that pass around it. The average plunge larly on its southern limb. The amphibolite is absent from many places. The entire fold is much constricted in the vicinity of Strafford Village but widens out farther west. The nose is very blunt, and the amphibolite in it has a wide outcrop. A unique characteristic of this nose is the marked concentration at its northern 
"corner" of coarse garnetiferous schist in the Waits River formation beneath the amphibolite. The average plunge of minor folds near the nose is $20^{\circ}$ north-northeast.

On the west limb of the cleavage arch is a group of folds that, in most respects, form mirror images of the anticlines and synclines just described. The first outcrops of amphibolite southwest of the crest of the arch outline a syncline $\left(A^{\prime}\right.$ in fig. Io). Like the Strafford Village syncline, this fold is isoclinal. All the stratigraphic units are much thinned, and the amphibolite is locally absent. The fold is more constricted near its "root" than farther north, the nose is very blunt, and the amphibolite in the nose has a large breadth of outcrop.

Moreover, a very prominent concentration of garnetiferous schist is present in the Waits River formation beneath the amphibolite on the western "corner" of this nose. The average plunge of minor folds near the nose is $25^{\circ}$ southwest, in the opposite direction from the plunge of analogous folds in the Strafford Village syncline. There can be little doubt that this fold is merely the Strafford Village syncline exposed on the opposite, or western, flank of the cleavage arch.

The anticline adjacent to the syncline just described shows a similar correspondence of distinctive characteristics with the Grannyhand anticline on the eastern limb of the cleavage arch and can be correlated with it. In the same way the syncline farther southwest corresponds to the Old City syncline.

The amphibolite on the southern flank of the Strafford Village syncline was traced by Doll around the cleavage dome in the southern part of the Strafford quadrangle. As shown in figure 2, this trace is relatively smooth and has no sharp flexures like those near Strafford
Village. It seems likely, therefore, that the amphibolite that skirts the crestal part of the dome is everywhere on the same limb of the same isoclinal foldspecifically, the structurally lower limb of the Strafford Village syncline.

The correlation of these folds is diagrammatically presented in the tectonic map (fig. Io) and block diagram (fig. I I) of the Strafford Village area. The trace of the axial plane of the Strafford Village syncline (line $A$ in fig. Io) doubles back on itself where it crosses the axial plane of the cleavage arch and joins line $A^{\prime}$ on the western flank of this arch. This axial plane has not been actually mapped in the Waits River formation, but some such connection is almost certain. Traces of the axial planes of the structurally higher folds presumably pass around the crest of the cleavage arch farther to the north, beyond the Strafford Village area (cf. $B$ and $B^{\prime}, C$ and $C^{\prime}$, fig. Io).

Axes of the folds are shown in horizontal projection by rows of arrows (lines $D$, $E$, and $F$, fig. 10). Although these axes diverge markedly from one another, all are essentially normal to the trace of the axial plane of the cleavage arch where they cross it. There is a close relationship in space between the isoclinal folds and the curve in the axial plane of the cleavage arch, and a possible explanation of this coincidence is presented in the summary of regional structure.

It is apparent from the foregoing discussion that the cleavage arch that dominates the central tectonic belt is not a simple anticline with older beds in the core and an uninterrupted sequence of successively younger beds on the flanks. The units that have been bowed up to form the arch are not stratigraphic units but, rather, are large isoclinal folds, similar in appearance, though probably not in origin, to the recumbent folds of the Alps. 


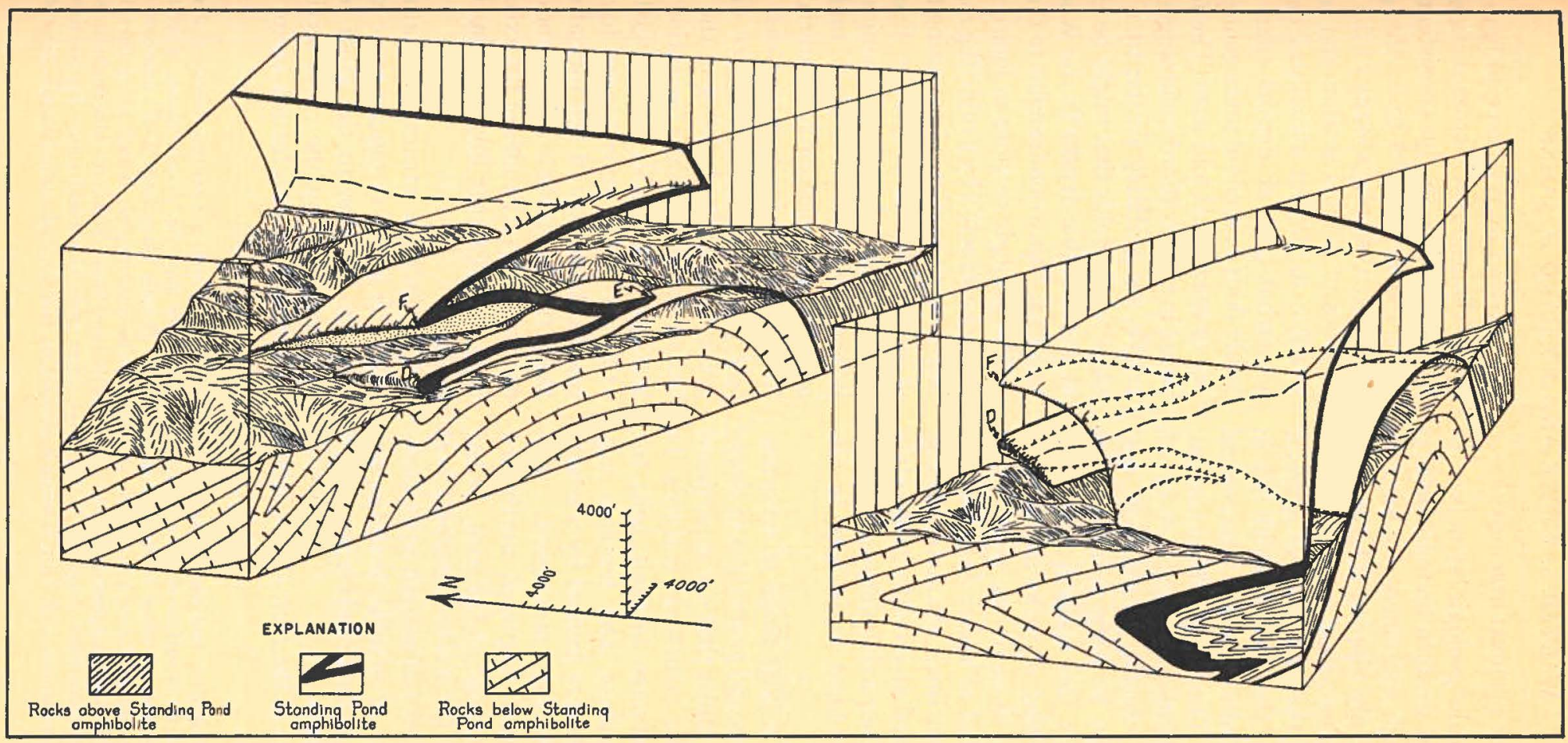

FIG. Ir.-Block diagram of the Strafford Village area (see figs. $g$ and ro), showing folds restored above present land surface. Original block is cut and pulled apart to indicate appearance of folds in section. Fold axes are identified by same letters"as in fig. Io. 
SUMMARY OF REGIONAL STRUCTURE

The large-scale geologic structure of the eastern and western tectonic belts is simple, although extremely complex in detail. The steeply dipping stratigraphic units form a homoclinal series that appears to lie on the east flank of a major anticlinal arch, the axis of which lies in the Green Mountains, west of the central Vermont area. This Green Mountain anticline is evidently the product of an early stage of crustal deformation, and subsidiary folds in both tectonic belts demonstrate for this stage a consistent upward movement of rocks on the east with respect to those on the west. These folds, interpreted as minor drag folds on the major anticline, characteristically plunge northward at small to moderately large angles. Their axial planes are parallel to a well-defined schistosity in the rocks.

Products of a later stage of deformation include a second generation of cleavage, folds, and faults that are superposed upon the earlier structural features. In parts of the western tectonic belt, the orientation of these later features suggests that they were formed by a nearly horizontal shearing movement, with rocks on the east displaced northward with respect to those on the west. In the eastern part of the western tectonic belt and in the central and eastern belts, however, the later structural features are closely related to the broad cleavage arch in the central belt.

The structure of the central belt is best summarized by reference to figure 2 and to the diagrammatic cross sections in figure I 2. Owing to the consistent northward plunge of fold axes, the geologic map (fig. 2) displays many of the characteristics of a cross section and makes it possible to project structural details to somewhat greater depths than can be safely done in areas of more gently plunging or horizontal fold axes. The folds exposed in the Strafford quadrangle, for example, are probably similar to, if not the same as, the folds that might be expected at considerable depths in the Woodsville and East Barre quadrangles to the north.

The geologic sections in figure $\mathrm{I} 2$ have been constructed by projecting map data into a single vertical plane, using the axes of minor folds as projection lines. This construction is largely mechanical in the interval between lines $X-X^{\prime}$ and $Y-Y^{\prime}$, and the only interpretive material in this interval is the fault on the east side of $G M($ ?) in section $A$, and the diagram. matic folds in the bedding of the eastern belt of the Waits River formation in both sections. These folds are justified by the existence of the same type of fold in the eastern boundary of the formation, and the attitudes of their axial planes closely represent the attitudes of the axial planes of observed minor folds within the ares mapped.

The unusual structural features revealed in figure $\mathrm{I} 2$ require some explana. tion. In addition to the gross relation. ships revealed by the cross section, the following data also form a major part of

Fic. I2. - Diagrammatic east-west structure sections of central and east-central Vermont, showing trio possible interpretations of surface relations. Data projected from map (fig. 2) onto planes of sections, with northward-plunging axes of minor folds as projection lines. Details along lines $X-X^{\prime}$ represent structurt exposed in northern part of Barre, East Barre, and Woodsville quadrangles; details along lines $Y-Y^{\prime}$ rep resent structure at surface at approximate latitude of Bethel and South Strafford. Meetinghouse slate, net to Monroe fault, omitted from diagram. $P-N s$, rocks older than Northfield slate; $N s$, Northfield slate $W R$, Waits River formation; $G M$, Gile Mountain formation; $G M($ ?), rocks provisionally assigned to $G$ il Mountain formation. 

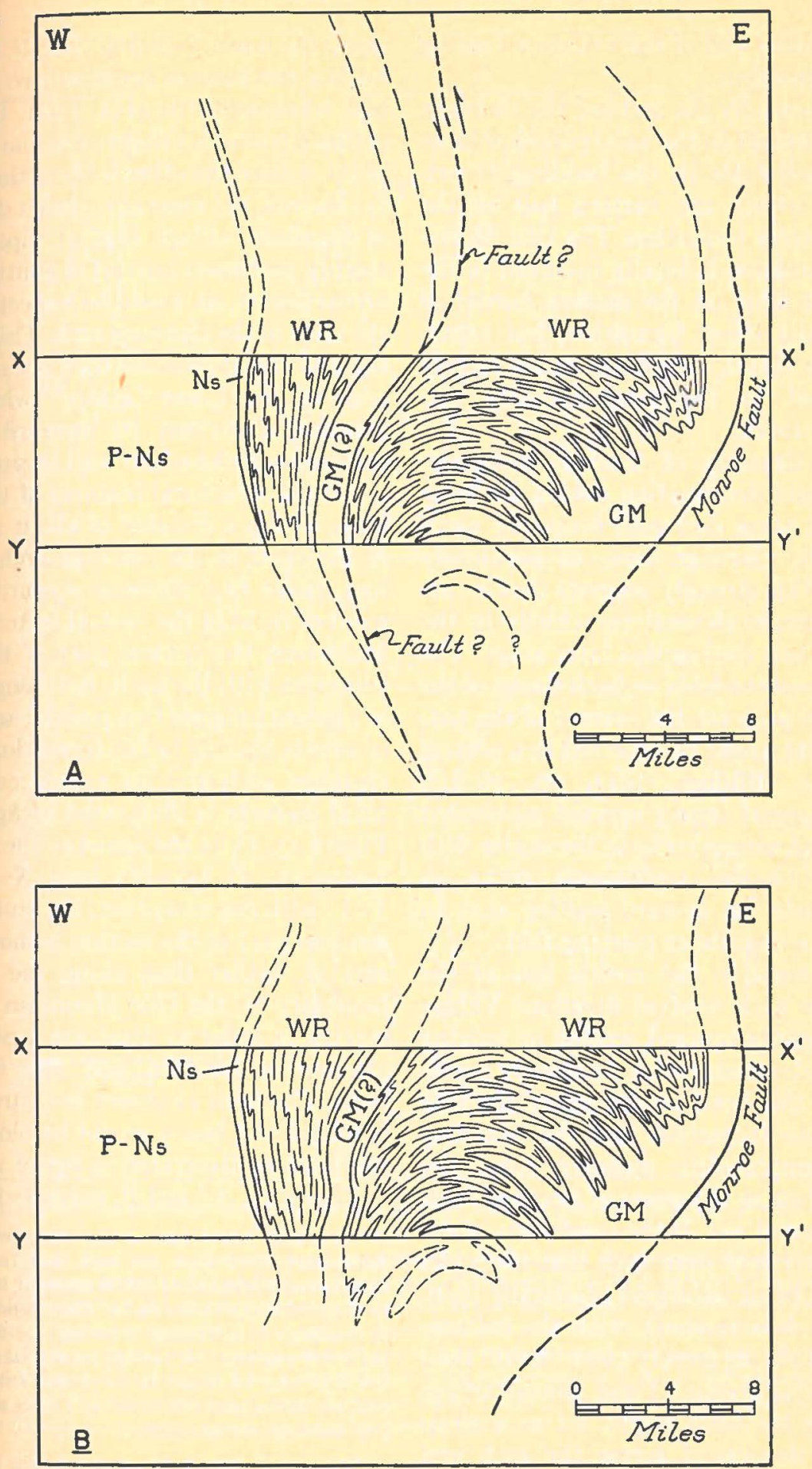

FIG. I 2.-(Legend on facing page) 
the problem and of the evidence bearing on the problem.

As shown by the section, the cleavage arch, a flexure in the axial planes of large and small folds in the bedding, is primarily within the eastern belt of the Waits River formation. The Gile Mountain formation is locally involved in the isoclinal folds on the eastern border of the Waits River formation, but otherwise the major complications are largely restricted to the predominantly calcareous rocks.

The intensity of thermal metamorphism and deformation during the later tectonic stage decreases markedly away from the cleavage arch, as previously noted. This strongly suggests that an active tectonic element lay chiefly in the central belt during this later stage. The patterns of the folds on both flanks of the cleavage arch are the reverse of the patterns that would be expected in a normal anticline (Billings, I942, pp. 76-8I). They suggest strong upward movement of the calcareous rocks in the center with respect to the argillaceous rocks on either side, an upward welling akin to that in a diapiric or piercing fold.

The bend in the crestal line of the cleavage arch west of Strafford Village also suggests upward welling or bulging of the calcareous rocks. As already pointed out, this bend occurs where the Gile Mountain formation and the Standing Pond amphibolite member cross the crestal line in the noses of isoclinal folds (figs. Io and II). If the conditions of deformation here were such that the rocks were all being deformed plastically (continuous deformation), with the calcareous rocks being merely more "fluid" than the noncalcareous, ${ }^{5}$ these noncalcareous rocks in the folds might act as a strap pulling downward across the arch and hence would inhibit upward bulging along the line of crossing (line $D$, fig. Io). Such a mechanism explains two anomalous features of the area. First, the nose of the Strafford Village syncline is very blunt, unlike the other folds of the vicinity. Second, the cleavage 2 miles due west of Strafford village (fig. 9) dips rather steeply southeast instead of gently north or northwest, as would be expected near the crest of the cleavage arch. This blunting and the anomalous dips occur at the edge of the lower "strap," where the greatest distortion by upward-welling calcareous rocks might well be predicted.

All the structural features of the later stage within a distance of about Io miles of the crest of the cleavage arch, therefore, point to a common upward movement of rocks of the central tectonic belt. Moreover, the central part of this belt coincides with the arch, itself suggestive of upward bulging. One possible sequence of events leading to the formation of the cleavage arch and its associated structural features is illustrated in figure $I 3$. Figure $\mathrm{I}_{3}, C$, is the same as the part of figure I2, $A$, between lines $X-X^{\prime}$ and $Y-Y^{\prime}$ with one exception; the fault in the western part of the section is shown just east of, rather than along the eastern boundary of, the Gile Mountain (?) formation in order to illustrate a preferred alternative location and age for this fault. The fault as shown in figure $12, A$, is folded and hence would be older than the fault as illustrated in figure 13 .

Figure $\mathrm{I}_{3}, A,{ }^{6}$ and $B$, suggests that the

$s$ One may safely assume that the conditions of deformation here were not such that the noncal. careous rocks behaved as brittle material, in contrast to the plastic calcareous rocks. There is no evidence of boudinage in individual outcrops, and the Stand. ing Pond amphibolite, though locally thinned to 3 few feet, can be found in its proper stratigraphir position throughout the Strafford Village area wher ever outcrops are adequate.

${ }^{6}$ Section $A$ extends to greater depths than mas seem reasonable to some geologists, even for fold 


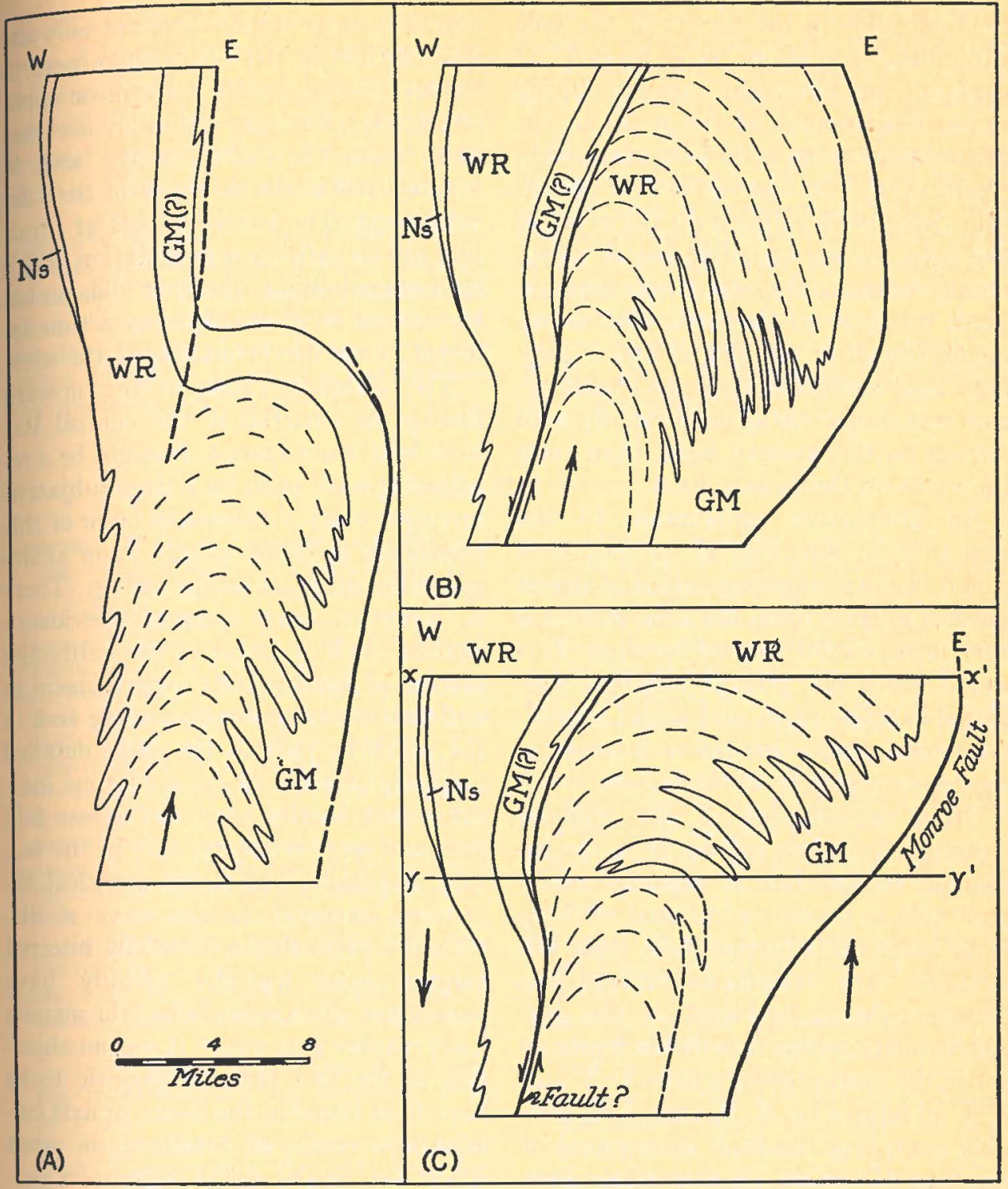

FIG. 13.-Diagrammatic east-west vertical sections showing possible evolution of structure in the central tectonic belt. Letter symbols are same as in fig. I 2. Meetinghouse slate, next to Monroe fault, omitted from diagram. $A$, cleavage arch (suggested by dashed lines representing schistosity and axial planes of minor folds) begins to form, owing to upward flowage. $B$, folds in eastern boundary of Waits River formation become elongate and almost isoclinal as they are brought together by continued upward transport; faulting along west side of arch. $C$, eastern side of area rises with respect to western, and isoclinal folds are rotated into cleavage arch. $B$ and $C$ may have occurred simultaneously; that is, $C$ may have developed directly from $A$ by a combination of the movements of $B$ and $C$, but without any intervening stage $B$ distinct as such. Cause of upward push, $A$ and $B$, may be subjacent igneous rocks, extreme flowage of calcareous rocks, or a combination of factors. 
isoclinal folds in the border of the Gile Mountain formation were formed by drag and were brought together during upward movement of the rocks in the central part of the arch. It is assumed in figure $\mathrm{I}_{3}, C$, that the folded Gile Mountain rocks were rolled over the crest of the arch by vertical differential movement, rocks on the east rising with respect to those on the west. The movements shown in sections $B$ and $C$ may have been simultaneous if the crestal region was simply rising more rapidly with respect to the western flank than were the rocks on the eastern flank.

An alternative explanation of the structure in the central tectonic belt would involve superimposition of major upward bulging upon the axial part of a very large, earlier-formed syncline. This would yield the general relations suggested in figure I2, $B$, and would necessitate some major changes in interpretation of stratigraphy in the region.

Other explanations of the regional structure doubtless will occur to the ingenious reader, but it scarcely seems profitable to present additional working hypotheses until further field data are obtained. Any reasonable explanation, however, should be based on the geometric relationships revealed in figure ro and in the spaces between lines $X-X^{\prime}$ and $Y-Y^{\prime}$ of figures $\mathrm{I} 2, A, B$, and $\mathrm{I}_{3}, C$, possibly excepting the fault shown east of the Gile Mountain (?) formation. Furthermore, it should not neglect the close connection between the upward arching and the patterns of the later minor folds on the flanks, particularly the dextral later-stage folds of the eastern tectonic

geosynclines, and in construction there may have been assumed more vertical transport than is necessary to form the isoclinal folds of the Strafford and adjacent quadrangles. Or perhaps the formations were more gently inclined at the stage represented by section $A$. belt. The later minor folds not only are symmetrical in pattern with respect to the arch (i.e., opposite patterns on opposite flanks), but they definitely decrease away from the center of the arch in number and in the intensity of their development. The isoclinal folds at Strafford are an extreme manifestation of this later-stage folding. The later folds probably cannot be divorced, as by a time-interval, from the formation of the arch.

The ultimate cause of the upward flowage of material in the central tectonic belt is not known. It might be a result of upward push by a large subjacent intrusive mass. Evidence in favor of this possibility is based largely upon analogy with other, near-by areas. There is, however, some suggestive evidence against such a cause. First, although plutons of Barre granite are prominent in and near the crestal region of the arch in the northern part of the area, detailed mapping of some of these plutons indicates that locally they cut across fold axes and were relatively late in the tectonic sequence. This is not a critical objection, inasmuch as the wave of disturbance preceding a forcefully injected magma must logically already have passed any given point before the magma itself reaches that point. A second objection is the fact that no granitic rocks have been found in the dome, or axis culmination, south of Strafford, in what might well be the apical region of a postulated subjacent intrusive. In fact, even small dikes of granitic rocks are rare in the entire Strafford quadrangle.

The upward migration of material may well have been assisted by the extreme mobility of calcareous rocks during deep-seated deformation; that is, the origin of the cleavage arch might have something in common with the formation of salt domes. The best evidence in favor 
of such rock flowage is seen in many outcrops of interbedded calcareous and noncalcareous rocks, where the attenuated isoclinal folds in the calcareous layers contrast strongly with the more open folds in adjacent noncalcareous layers.

ACKNOWLEDGMENTS. - The writers are indebted to Jarvis B. Hadley, of the U.S. Geological Survey, who has generously permitted the use of his unpublished maps of the Vermont part of the Mount Cube quadrangle. They have profited throughout the period of investigations from discussions with Hadley, L. W. Currier, and R. S. Cannon, Jr., of the Geological Survey, and with M. P. Billings, of Harvard University. White gratefully acknowledges the capable work of J. H. Eric, Edgar Breed, Richard H. Story, and Ralph Hornblower, Jr., each of whom spent a summer as a field assistant in the Woodsville quadrangle. Eric and T. W. Amsden also did much of the subsequent geologic mapping in the Orange County copper district. Most of the illustrations were drafted by Joan $T$. Rounds, of the California Institute of Technology. Considerable improvement in the manuscript resulted from the careful criticism of W. M. Cady, J. B. Hadley, and P. B. King, of the Geological Survey.

\section{REFERENCES CITED}

Ambrose, J. W. (I942) Preliminary map, Mansonville, Quebec: Canada Geol. Survey Paper 42-r. _ (I943) Preliminary map, Stanstead, Quebec: ibid., Paper 43-I2.

ANDERSON, E. M. (1942) The dynamics of faulting, Edinburgh, Oliver \& Boyd, I9r pp.

BALK, ROBERT (1927) A contribution to the structural relations of the granitic intrusions of Bethel, Barre, and Woodbury, Vermont: Vermont State Geologist r 5 th Rept., pp. 39-96.

- (1936) Structural and petrologic studies in Dutchess County, New York, pt. 1: Geol. Soc. America Bull. 47, pp. 685-774.

Biluings, M. P. (1937) Regional metamorphism of the Littleton-Moosilauke area, New Hampshire: Geol. Soc. America Bull. 48, pp. 463-566.

- (1942) Structural geology, New York, Prentice-Hall, Inc., 473 pp.

ClaRK, T. H. (r 934) Structure and stratigraphy of southern Quebec: Geol. Soc. America Bull. 45, pp. $\mathbf{x}-20$.

(1936) Silurian rocks of Lake Memphremagog, Quebec: Canadian Field Naturalist, vol. 5०, pp. 3I-33.

Cloos, ERNST (1947) Oölite deformation in the South Mountain fold, Maryland: Geol. Soc. America Bull. 58, pp. 843-9r8.

Currier, L. W., and Jahns, R. H. (I94I) Ordovician stratigraphy of central Vermont: Geol. Soc. America Bull. 52, pp. 1487-I5I2.

DALE, T. N. (1899) The slate belt of eastern New York and western Vermont: U.S. Geol. Survey Igth Ann. Rept., pt. 3, pp. I53-300.

- (1923) The commercial granites of New England: U.S. Geol. Survey Bull. 738, 488 pp.

Doll, C. G. (I943a) A Paleozoic revision in Vermont: Am. Jour. Sci., vol. 24I, pp. 57-64.

- (1943b) A brachiopod from mica schist, South Strafford, Vermont, ibid., pp. 676-679.
(I945) A preliminary report on the geology of the Strafford quadrangle, Vermont: Vermont State Geologist 24th Rept., pp. I4-28.

ElLs, R. W. ( 1887 ) Report on the geology of a portion of the eastern townships of Quebec: Canada Geol. Survey Ann. Rept., no. 2, pp. IJ-70J.

ERIC, J. H.; WhITE, W. S.; and HADLEY, J. B. (I94I) Monroe fault of New Hampshire and Vermont (abstr.): Geol. Soc. America Bull. 52, p. Igoo.

FAIRBAIRN, H. W. (1932) Structure and metamorphism of Brome County, Quebec, Doctor's dissertation, Harvard University.

Finlay, G. I. (IgO2) The granite area of Barre, Vermont: Vermont State Geologist 3d Rept., pp. 46-6o.

Foyles, E. J. (193I) Compressed mica resembling graptolites: Vermont State Geologist I 7 th Rept., p. 252.

HadLey, J. B. (1942) Stratigraphy, structure, and petrology of the Mt. Cube area, New Hampshire: Geol. Soc. America Bull. 53, pp. I I $3-$ I 76 .

HAwKes, H. E., JR. (I94I) Roots of the Taconic fault in west-central Vermont: Geol. Soc. America Bull. 52, pp. 649-666.

Hгтснсоск, C. H. (I I 2) The Strafford quadrangle, Vermont: Vermont State Geologist 8th Rept., pp. roo-I45.

HitchсOcK, EDWARD, et al. (I86I) Report on the geology of Vermont, Burlington, Vermont Geol. Survey, 2 vols., 982 pp.

KERR, F. A. (I923) Unpublished report on the southeast part of the Memphremagog sheet, Quebec: Canada Geol. Survey (loaned by T. H. Clark). Largely abstracted in Ambrose (I943).

Perry, E. L. (Ig29) The geology of Bridgewater and Plymouth townships, Vermont: Vermont State Geologist I6th Rept., pp. 1-64. 
Richardson, C. H. (IgO2) The terranes of Orange County, Vermont: Vermont State Geologist $3 \mathrm{~d}$ Rept., pp. 6r-Ior.

- (1906) The areal and economic geology of northeastern Vermont: ibid., 5th Rept., pp. 63 -II5.

(I916) The geology of Calais, East Montpelier, Montpelier, and Berlin, Vermont: ibid., roth Rept., pp. III-I49.

(IgIga) The Ordovician terranes of central Vermont: ibid., II th Rept., pp. 45-51.

- $(I g I g b)$ The terranes of Roxbury, Vermont:

ibid., pp. I 20-I40.

(I924) The terranes of Bethel, Vermont: ibid., I4th Rept., pp. 77-103.

- (I927) The geology and petrography of Barnard, Pomfret, and Woodstock, Vermont: ibid., 15 th Rept., pp. 1 $27^{-1} 59$.

(1929) The geology and petrography of Reading, Cavendish, Baltimore, and Chester, Vermont: $i b i d$., 16th Rept., pp. 208-248. and CABEEN, C. K. (Ig2I) The geology and mineralogy of Braintree, Vermont: Vermont State Geologist I 2th Rept., pp. 57-76.

(I923) The geology and petrogra-

phy of Randolph, Vermont: ibid., I3th Rept., pp. IO9-I42.

- and CAMp, S. H. (rgrg) The terranes of Northfield, Vermont: Vermont State Geologist II th Rept., pp. 99-II9.

and MAYNaRD, J. E. (I939) Geology of Vernon, Guilford, and Halifax, Vermont: Vermont State Geologist 21st Rept., pp. 84-96.

WHITE, W. S. (I949) Cleavage in east-central Vermont: Am. Geophys. Union Trans., vol. 30, pp. 587-594.

- and Eric, J. H. (I944) Geology of the Orange County copper district, Vermont: U.S. Geol. Survey, Strategic Minerals Inv., preliminary maps.

Williams, C. R., and Billings, M. P. (I938) Petrology and structure of the Franconia quadrangle, New Hampshire: Geol. Soc. America Bull. 49, Pp. IOII-IO44. 